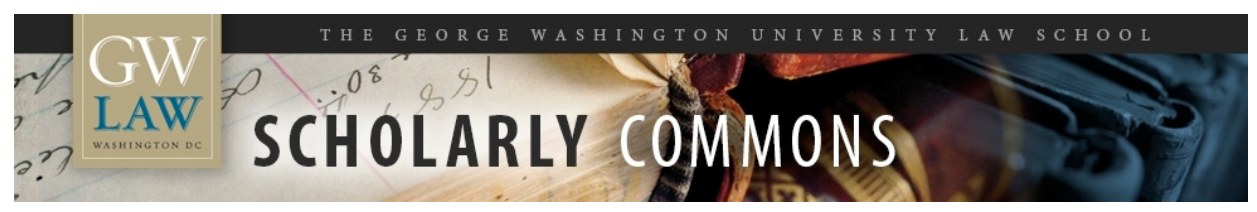

\title{
How American Rejectionism Undermines International Economic Law
}

Steve Charnovitz

George Washington University Law School, scharnovitz@law.gwu.edu

Follow this and additional works at: https://scholarship.law.gwu.edu/faculty_publications

Part of the Law Commons

\section{Recommended Citation}

Charnovitz, Steve, How American Rejectionism Undermines International Economic Law (2018). 10(2) TRADE L. \& DEV. 226 (2018) ; GWU Law School Public Law Research Paper No. 2019-7 ; GWU Legal Studies Research Paper No. 2019-7. Available at SSRN: https://ssrn.com/abstract=3357030

This Article is brought to you for free and open access by the Faculty Scholarship at Scholarly Commons. It has been accepted for inclusion in GW Law Faculty Publications \& Other Works by an authorized administrator of Scholarly Commons. For more information, please contact spagel@law.gwu.edu. 
Trade, Law and Development

Steve Charnovitz, How American Rejectionism

Undermines International Economic Law

10(2) TRAde L. \& DeV. 226 (2018)

\title{
HOW AMERICAN REJECTIONISM UNDERMINES INTERNATIONAL ECONOMIC LAW
}

\author{
STEVE CHARNOvitZ*
}

The completion of the Trump Administration's first two years is an appropriate moment to take stock of the United States of America's aggressive international economic policies. The Trump Administration is carrying out a new form of American rejectionism powered by four horsemen of economic instability: first, the rejection of the international rule of law; second, the rejection of open markets; third, the rejection of economic peace in favour of perpetual economic war; and fourth, the rejection of the global interest. The analysis herein shows how these four rejectionist policies are harming the United States, other countries, and the global order. With respect to the global order, the article focuses on the World Trade Organization (WTO), regional trade agreements, and the Paris Agreement on Climate Change, and explains how the Trump Administration is attacking these important institutions.

In doing so, the article challenges three widely-held assumptions. First, the article shows that in several important respects, American rejectionism did not begin with President Trump but rather was rooted in the economic policies of his recent Presidential predecessors, especially President Obama. Second, the article shows that far from being the leading scofflaw in the WTO, China is not acting nearly as irresponsibly as the United States does in its constant and flagrant violations of international trade law. Third, the article shows that the protectionist economic policies being pursued by the Trump Administration are unlikely to generate any short term gains for the US economy, and over time such policies will exact a loss for the US and global economy.

Several recommendations are offered for ways to improve US policies going forward. Among them are: ceasing the US war against the WTO Appellate Body, reinvigorating international trade negotiations, working with other countries to develop rules for the transition of nonmarket economies, and seeking

\footnotetext{
* Steve Charnovitz is a law professor at George Washington University in Washington, DC.
}

This article is current as of January 15, 2019. Contact: scharnovitz[at]law.gwu.edu. 
a critical-mass international agreement to impose carbon charges so as to internalise the costs of greenhouse gas emissions.

\section{TABLE OF CONTENTS}

\section{INTRODUCTION \\ II. RETREAT From A LAW-CENTRED MULTILATERAL ECONOMIC ORDER \\ A. THE OBAMA ADMINISTRATION \\ B. THE TRUMP ADMINISTRATION}

III. RETREAT FROM FREE TRADE

A. THE OBAMA ADMINISTRATION

B. THE TRUMP ADMINISTRATION

IV. RETREAT FROM ECONOMIC PEACE

V. RETREAT FROM THE GLOBAL ORDER

VI. CONCLUSION

\section{INTRODUCTION}

During the first two years of the Trump Administration, its new policies have shaken world economic and ecological foundations, with more toxic potential than any prior policy shift in United States' (US) foreign economic policy. ${ }^{1}$ The stated aim of the Trump Administration is to 'Make America Great Again'2 by disengaging from global governance and lowering the US trade deficit. But any economic gain that might ensue for the US economy will surely come at the expense of other economies, particularly middle income countries such as China, Mexico, and India. The unlikelihood of effectuating any aggregate benefits to the world economy is a consequence of the unwise policy choices being made by the Trump Administration. Even if protectionism, unilateralism, and isolationism were to pay off for the US economy, such actions cannot possibly be a formula for collective economic progress to be emulated by all countries.

\footnotetext{
1 See generally Douglas A. Irwin, Clashing Over Commerce: A History of US TRAde POLICY (1st ed. 2017), which discusses the audacity of the Nixon Administration in 1971 to abandon the dollar-gold convertibility of the Bretton Woods system and to impose a ten percent import surcharge. However unwise it was, the import surcharge lasted only a few months and the move to floating currencies led to greater systemic stability.

2 The Life, Love and Legacy of George H.W. Bush, POLITICO (Nov. 30, 2018,), https://www.politico.com/gallery/2017/12/13/george-hw-bush-life-in-photos-

002736? slide $=15$, referencing a slogan from Ronald Reagan's successful 1980 Presidential campaign, later copied by Donald Trump.
} 
To assign the Trump Administration full responsibility for wreaking such havoc is to give it too much credit for ingenuity. All of the counterproductive impulses animating President Trump have antecedents in the economic nationalism pursued by Trump's predecessors, particularly the Obama Administration. The ravages of these beggar-thy-neighbour policies in the US will continue to have negative repercussions even after Trump himself leaves the White House. Neither US political party supports free trade. ${ }^{3}$ Restoring a constructive international economic role for America could take a generation to accomplish.

Four potent ideas characterise Trump's rejectionist economic policies. First, Trump rejects an economic order based on the international rule of law and instead seeks to revert to an international order based on power. Second, Trump rejects human freedom and open markets as orienting principles for the global economy and chooses instead policies based on protectionism and autarky. Third, Trump rejects economic peace in favour of permanent economic war by the US against alleged transgressions by other countries. Fourth, Trump rejects the pursuit of global interest or the interest of humanity by the US and instead argues that each government focus on its own national interest. While each of these ideas will be discussed separately below, there are infectious overlaps between them.

Following this Introduction, the article proceeds in five parts. Part II discusses how the US has been moving away from a law-centred, multilateral international economic order. Part III discusses how the US has been moving away from free trade and has instead embraced protectionism and import substitution. Part IV discusses how the US is engaging in perpetual economic war against major trading partners, especially China. Part V discusses how the US has been turning away from the global order promoting the common interests of mankind. A brief Part VI draws conclusions and looks to the future.

\section{RETREAT FROM A LAW-CENTRED MULTILATERAL ECONOMIC ORDER}

The Trump Administration sees power rather than law as the most important principle of international relations. Trump's National Security Strategy, announced in December 2017, claims to be "realist because it acknowledges the central role of

\footnotetext{
${ }^{3}$ But see James Bacchus, Democrats, Free Trade is Your Destiny, Wall St. J. OPInIOn, Dec. 3, 2018, 6:36 PM, https://www.wsj.com/articles/democrats-free-trade-is-your-destiny1543880165, where former US Congressman Jim Bacchus opined optimistically that US Congressional Democrats might reinvent themselves as supporters of free trade.
} 
power in international policies. ${ }^{4}$ To be sure, power is needed to enforce law. But Trump seems to endorse raw power without any control by law.

Nowhere can this been seen more clearly than in Trump's trade policy.

The WTO is a unique multilateral institution that provides enforceable rules for government involvement in international trade and provides a central institution for coordinating trade policy among countries. All of these key features of the WTO have been assaulted by the Trump Administration. Through a flurry of unilateral and protectionist trade actions, the Trump Administration has caused the US to repeatedly violate the rules of the Agreement Establishing the WTO (WTO Agreement). By threatening to quit the $\mathrm{WTO}^{5}$ and the North American Free Trade Agreement (NAFTA) ${ }^{6}$, and by withdrawing from the Trans-Pacific Partnership (TPP), the Trump Administration has threatened the stability of these important global institutions. Part II will provide a brief survey of these developments.

\section{A. The Obama Administration}

Yet, while the level of aggression against international law by the US is much higher under the Trump Administration than before it, many of the seeds of US rejectionism were planted before Trump. In the latter part of the Obama Administration, several countries won ten WTO cases against actions of the US Executive Branch or the Congress. For example, in the US - Shrimp and Sawblades dispute, the WTO Dispute Settlement Body (DSB) upheld China's complaint that the US Department of Commerce (USDOC) had violated the WTO Agreement on

\footnotetext{
${ }^{4}$ National Security Strategy of the United States of America, THE WHITE HOUSE, at 55 (Dec. 2017), https://www.whitehouse.gov/wp-content/uploads/2017/12/NSS-Final-12-18-20170905.pdf (last visited Feb. 13, 2019). US law requires the President to submit an annual National Security Strategy. National Security Act of 1947 \ 108, 50 U.S.C. \404a (2012). Although the Obama Administration failed to meet this important legal requirement in six of its eight years in office, the Trump Administration has followed the law. See NATIONAL SECURITY STRATEGY ARCHIVE, http://nssarchive.us. ${ }^{5}$ Christine Wang, Trump Threatens to Withdraw From the World Trade Organization, CNBC, Aug. 30, 2018, 4:28 PM, https://www.cnbc.com/2018/08/30/trump-threatens-to-withdraw-from-world-tradeorganization.html.

${ }^{5}$ Christine Wang, Trump Threatens to Withdraw From the World Trade Organization, CNBC, Aug. 30, 2018, 4:28 PM, https://www.cnbc.com/2018/08/30/trump-threatens-to-withdrawfrom-world-trade-organization.html.

${ }^{6}$ Lisa Lambert, Trump Threatens to Scrap NAFTA in Sunday Morning Tweet, CNBC, Aug. 27, 2017, 11:38 AM, https://www.cnbc.com/2017/08/27/trump-threatens-to-scrap-nafta-insunday-morning-tweet.html.
} 
the Implementation of Article VI of GATT 1994 (Antidumping Agreement). ${ }^{7}$ In the US -Countervailing and Anti-Dumping Measures dispute, the DSB upheld China's complaint that USDOC had violated the WTO Agreement on Subsidies and Countervailing Measures (SCM). ${ }^{8}$ In the US - Carbon Steel dispute, the DSB upheld India's complaint that the USDOC had committed multiple violations of the SCM Agreement. ${ }^{9}$ In the US - Countervailing Measures dispute, the DSB upheld China's complaint that USDOC had violated the SCM Agreement. ${ }^{10}$ In the compliance review in the US - COOL dispute, the DSB upheld Canada and Mexico's complaint that the US had failed to comply with a previous WTO ruling that had criticised US violations of the WTO Agreement on Technical Barriers to Trade (TBT). ${ }^{11}$ Subsequently, a WTO arbitrator authorised the two North American countries to together impose an 'SCOO'12 against the US to block over $\$ 1$ billion in US exports. ${ }^{13}$ In the US - Animals dispute, the DSB upheld Argentina's complaint that the US government had committed multiple violations of the WTO Agreement on Agriculture. ${ }^{14}$ In the compliance review in the US - Tuna II dispute, the DSB upheld Mexico's complaint that the US had failed to comply with a previous WTO ruling regarding US' violations of the General Agreement on Tariffs and Trade (GATT) and the TBT Agreement. ${ }^{15}$ Subsequently, a WTO arbitrator authorised

\footnotetext{
${ }^{7}$ Panel Report, United States - Anti-Dumping Measures on Certain Shrimp and Diamond Sawblades from China, WTO Doc. WT/DS422/R (June 8, 2012).

${ }_{8}$ Appellate Body Report, United States - Countervailing and Anti-Dumping Measures on Certain Products from China, WTO Doc. WT/DS449/AB/R (July 7, 2014).

${ }^{9}$ Panel Report, United States - Countervailing Measures on Certain Hot-Rolled Carbon Steel Flat Products from India, WTO Doc. WT/DS436/R (July 14, 2014).

${ }^{10}$ Appellate Body Report, United States - Countervailing Duty Measures on Certain Products from China, WTO Doc. WT/DS437/AB/R (Dec. 18, 2014).

11 Appellate Body Report, United States - Certain Country of Origin Labelling (COOL) Requirements, WTO Doc. W'T/DS384/AB/RW, WT/DS386/AB/RW (May 18, 2015).

12 The "SCOO" is a remedy provided for in the WTO Dispute Settlement Understanding (DSU) against a country whose government fails to comply with a WTO ruling against it. SCOO stands for 'Suspension of Concessions or Other Obligations' and is provided in Article 22.1 of the DSU. An SCOO is a trade sanction that blocks exports of the defendant country. Under Art. 22.7 of the DSU, in the COOL case, the DSB implemented the report of the arbitrator by authorizing the complaining countries, Mexico and Canada, to impose an SCOO against the defendant United States.

${ }_{13}$ Decision by the Arbitrator, United States - Certain Country of Origin Labelling (COOL) Requirements, WTO Doc. WT/DS384/ARB, WT/DS386/ARB (Dec. 7, 2015).

${ }_{14}$ Panel Report, United States - Measures Affecting the Importation of Animals, Meat and Other Animal Products from Argentina, WTO Doc. WT/DS447/R (July 24, 2015).

${ }^{15}$ Appellate Body Report, United States - Measures Concerning the Importation, Marketing and Sale of Tuna and Tuna Products, WTO Doc. W'T/DS381/AB/RW/ (Dec. 14, 2018).
} 
Mexico to impose an SCOO against the US to block $\$ 163$ million in US exports. ${ }^{16}$ In the US - Washing Machines dispute, the DSB upheld Korea's complaint that the USDOC had committed multiple violations of the WTO Antidumping and SCM Agreements. ${ }^{17}$ In the US - Antidumping Methodologies dispute, the DSB upheld China's complaint that the USDOC had committed multiple violations of the Antidumping Agreement. ${ }^{18}$ With the possible exception of the Tuna II case, all the other nine cases were about clear protectionist acts of the Obama Administration or the US Congress. The role of China as the winning complaining party in four of these cases demonstrates both China's willingness to be a rule of law enforcer and the US' habit of being a W'TO law breaker.

Distressed at losing so many WTO cases, the Obama Administration struck back against the WTO Appellate Body in 2016 by blocking the reappointment of the distinguished Korean jurist, Seung Wha Chang, who had served on the Appellate Body division in the US - Countervailing Measures, the US - Countervailing and AntiDumping Measures, and the US - COOL cases (discussed above). This blatant attack on international judicial independence was criticised by many observers, ${ }^{19}$ but the Obama Administration was able to take advantage of the consensus rule in the DSB to block the anticipated reappointment. As a result, the DSB had to select a replacement judge from Korea after a delay of six months, caused by Obama's intransigence. As it turned out, the replacement appellator resigned after only eight months to become Korea's Trade Minister and his slot remains empty even today due to the Trump Administration's refusal to concur in filling any of the Appellate Body vacancies. So, the stubbornness of the Obama Administration not only caused a six-month judicial gap in 2016, but also led to an unfortunate chain of events whereby Chang's appellator slot has now been unnecessarily vacant for over sixteen months.

In addition to its poor stewardship of the US' long-time leadership role at the WTO, the Obama Administration also allowed NAFTA's governing institution, the NAFTA Free Trade Commission, to languish. The Commission has been so inactive

\footnotetext{
${ }^{16}$ Decision by the Arbitrator, United States - Measures Concerning the Importation, Marketing and Sale of Tuna and Tuna Products, WTO Doc. WT/DS381/ARB (Apr. 24, 2017).

${ }_{17}$ Panel Report, United States - Anti-Dumping and Countervailing Measures on Large Residential Washers from Korea, WTO Doc. WT/DS464/R (Mar. 11, 2016).

18 Panel Report, United States - Certain Methodologies and Their Application to Anti-Dumping Proceedings Involving China, WTO Doc. WT/DS471/R (Oct 19, 2016).

19 See, e.g., Steve Charnovitz, The Obama Administration's Attack on Appellate Body Independence Shows The Need for Reforms, INT'L ECON. L. \& POL'Y BLOG (Sept. 22, 2016, 6:23 PM), https://worldtradelaw.typepad.com/ielpblog/2016/09/the-obama-administrations-attackon-appellate-body-independence-shows-the-need-for-reforms-.html.
} 
that it does not have its own website, and according to a Canadian Government website, the last joint meeting or statement issued by the NAFTA Commission occurred on April 3, 2012. ${ }^{20}$ Deactivating the Commission was precisely the wrong approach at a time when public interest groups' criticisms of the NAFTA in the US, Canada, and Mexico were rising. The Commission was not a panacea, but surely a more active Commission could have become a forum to acknowledge and respond to growing public criticisms of the NAFTA. Moreover, the ministerial-level Commission could have overseen new negotiations to reform the NAFTA.

In eight years, the Obama Administration did not launch and complete the negotiation and implementation of a single US Free Trade Agreement (FTA). One reason was that the US fast track trade negotiating authority had expired during the George W. Bush Administration (Bush 43), but that deficiency could have been remedied if Obama had sought new authority early in his first term. Obama neglected to do so until his second term, and that authority was not enacted by the Congress until mid-2015. The new Bipartisan Congressional Trade Priorities and Accountability Act of 2015 installed greater Congressional procedural constraints than previous authorities, but the new law did enable the United States to participate successfully in the TPP negotiations. Two 'sovereignty' provisions in the new law are significant for showing the growing disaffection of the US Congress and the Obama Administration with international trade law. ${ }^{21}$ The first provision makes federal and subnational law superior to international law. ${ }^{22}$ This was a change from previous US trade law that had allowed the federal government to petition a US court to declare state or local law invalid for being inconsistent with WTO law. ${ }^{23}$ The second provision declares that international trade dispute panel decisions "shall have no binding effect on the law of the United States, the Government of the United States, or the law or government of any State or locality of the United States." 24 Apparently, the purpose of this provision was to chip away at the presumption that there is a compliance obligation under international trade law.

The Obama Administration's successful efforts to secure a new trade promotion authority from the Congress can be contrasted to the disinterest by the Obama Administration in securing any climate negotiating authority from the Congress. Climate law is different from trade law, of course, but both are part of an increasingly

\footnotetext{
20 See NAFTA Free Trade Commission, GovT. OF CANADA, http://www.international.gc.ca/trade-commerce/trade-agreements-accordscommerciaux/agr-acc/nafta-alena/fta-ale/celeb2.aspx?lang=eng.

2119 U.S.C. $\int 4207$ (2012).

2219 U.S.C. $\$ 4207$ (a) (2012).

23 See 19 U.S.C. $\$ 3512(b)(2)(2012)$.

2419 U.S.C. $\$ 4207$ (c) (2012).
} 
complex international economic law. In contrast to trade, the Obama Administration was quite active in multilateral climate negotiations but it did so with limited political support from the Congress. As a result, US nationalist objectives dictated a climate agreement that would be full of green symbolism but empty of any legal emission reduction commitments that would need to be ratified in the normal democratic process of Congressional approval and implementation. ${ }^{25}$ This was an expedient solution to enable the White House to enter into the Paris Agreement, with the hope of implementing it through the executive authorities.

To lead internationally, a US President needs two things: a constructive policy and US Congressional support. On trade, Obama gained Congressional support late in his Administration but did not have a constructive policy. On climate, Obama had a constructive policy but failed to gain Congressional support. Indeed, in order to secure new trade legislation in 2015, the Obama Administration agreed to a proviso in federal law insisting that new "trade agreements do not establish obligations for the United States regarding greenhouse gas emissions measures.”26

\section{B. The Trump Administration}

When President Trump took office in January 2017, the US was already a notorious trade scofflaw at the WTO, but the Trump Administration doubled down on such odious practices. The first attack on the rule of law was the move by the Trump Administration to stick with the Obama Administration's playbook ${ }^{27}$ by blocking appointments to the Appellate Body. The dangers of this non-cooperative stance were publicised by some commentators who offered advice on how WTO dispute settlement could be defended from the depredations of the Trump Administration. ${ }^{28}$

\footnotetext{
25 To be sure, many US climate partners were similarly pleased to be able to negotiate and trumpet a new climate agreement that did not require any concessions or legal commitments on their part.

2619 U.S.C. \$4201(a)(15) (2012).

27 The Obama Administration had blocked the reappointment of the Korean judge who otherwise would have been reappointed. The Trump Administration went further to block all new appellator appointments.

28 See, e.g., Steve Charnovitz, How to Save WTO Dispute Settlement from the Trump Administration, INT'L ECON. L. \& POL'Y BLOG (Nov. 3, 2017), https://worldtradelaw.typepad.com/ielpblog/2017/11/how-to-save-wto-disputesettlement-from-the-trump-administration.html; Pieter Jan Kuijper, The US Attack on the Appellate Body, INT'L ECON. L. \& POL'Y BLOG (Nov. 15, 2017), https://worldtradelaw.typepad.com/ielpblog/2017/11/guest-post-from-pieter-jan-kuiperprofessor-of-the-law-of-international-economic-organizations-at-the-faculty-of-law-ofth.html\#comments; Luiz Eduardo Salles, Bilateral Agreements as an Option to Living Through the WTO AB Crisis, INT'L ECON. L. \& POL’Y Blog (Nov. 23, 2017),
} 
Unfortunately, however, no defences were erected, and as of early 2019, the Appellate Body has only three appellators remaining and lacks the quorum to change any of its rules. ${ }^{29}$ As a result, delays in Appellate Body proceedings are getting worse. Two Appellate Body terms will expire on December 10, 2019, and at that time (or earlier if an appellator resigns or dies), the non-availability of an appeal will make W'TO panel reports unadoptable. ${ }^{30}$

Before the Trump Administration, the only part of the WTO that was working well was its judicial branch, but now, that too has been disabled. ${ }^{31}$ The Trump Administration has been coy as to what concessions would be enough for it to restart the Appellate Body appointments. Rather, the Administration has levied vague charges that the WTO's Dispute Settlement Understanding (DSU) "has sometimes been dominated by a dispute settlement system where activist judges' try to impose their own policy preferences on Member States."32 Without any apparent embarrassment over its unfair stance of blocking Appellate Body appointments, the Trump Administration has pledged that, "We will press to make the WTO a more effective forum to adjudicate unfair trade practices." 33

\footnotetext{
https://worldtradelaw.typepad.com/ielpblog/2017/11/guest-post-on-bilateralagreements-as-an-option-to-living-through-the-wto-ab-crisis.html.

${ }_{29}$ Alex Lawson, Trump's WTO Squeeze Still Sapping Appeals Process, LAW 360 (Oct. 23, 2018), https://www.law360.com/articles/1094936/trump-s-wto-squeeze-still-sapping-appealsprocess.

${ }^{30} \mathrm{Mr}$. Ujal Bhatia explained this succinctly while presenting the AB's Annual Report on June 22, 2018, "Where a panel report is appealed, but an Appellate Division cannot be formed to hear that appeal, the adoption of the panel report is suspended until the Appellate Body can complete its proceedings. This would lead to the de facto demise of the negative consensus rule that has characterized the WTO dispute settlement system since 1995." "Unprecedented Challenges" Confront Appellate Body, Chair Warns, World Trade OrGanization (June 22, 2018), https://www.wto.org/english/news_e/news18_e/ab_22jun18_e.htm.

31 The blocking of an appellator reappointment for political reasons by the Obama Administration was sharply criticised at the time by former Appellate Body members. D. Ravi Kanth, US Accused of Political Interference at the WTO, LIVEMINT (June 2, 2016), https://www.livemint.com/Politics/H2wpVj2RMsuNB4ODkFMbKP/US-accused-ofpolitical-interference-at-World-Trade-Organisa.html. But the conflict was solved with an alternative appointment that prevented any disabling of the Appellate Body.

32 United States Trade Representative, 2018 Trade Policy Agenda and 2017 Annual Report, The President's Trade Policy Agenda, at 2, https://ustr.gov/sites/default/files/files/Press/Reports/2018/AR/2018\%20Annual\%20R eport\%20I.pdf (last visited Jan. 5, 2018).

33 National Security Strategy of the United States of America, THE WHITE HOUSE (Dec. 2017) at 41, https://www.whitehouse.gov/wp-content/uploads/2017/12/NSS-Final-12-18-20170905.pdf (last visited Feb. 26, 2019).
} 
The Trump Administration has lodged several particular criticisms of Appellate Body practices such as that the Appellate Body has often failed to meet the ninetyday deadline (in DSU Article 17.5) for issuing decisions. ${ }^{34}$ While this complaint has justification, the reality that the ninety-day deadline is no longer realistic given how much more complicated WTO cases have gotten since 1995. Moreover, if the ninety-day deadline in the DSU has any parallel in any other international tribunal or in any national appellate tribunal, those examples have not come to the author's attention.

As of this writing, governments are engaged in intensive negotiations to relaunch Appellate Body appointments. ${ }^{35}$ Even if the crisis is solved before this article is published, the Appellate Body will not catch up on the backlog of cases for years to come. All the world sees the hypocrisy of the Trump Administration in complaining about slowness in WTO dispute settlement at the same time that it caused the bottleneck in the Appellate Body.

While the WTO violations by the Obama Administration were episodic, during the Trump Administration, the violations have become systemic. The most notorious actions are the tariffs being imposed under Sections 301 and 201 of the US Trade act of 1974, and Section 232 of the Trade Expansion Act of 1962. All of these tariffs violate WTO law. Asserting that actions by the government of China burden US commerce, the Trump Administration has used Section 301's ${ }^{36}$ tariff-imposing authority in a way that no US Administration had done since the WTO came into force. ${ }^{37}$ In announcing the tariff actions in March 2018, the Trump Administration accused China of multiple sins, including pressuring US companies in China for technology transfer, restricting the licensing terms of US technology, seeking to acquire US companies, and conducting and supporting unauthorized intrusions and

${ }^{34}$ US Opens New Front Against Appellate Body Over Delayed Reports, World Trade OnLINE (June 22, 2018), https://insidetrade.com/daily-news/us-opens-new-front-against-appellatebody-over-delayed-reports.

35 See, e.g., India Askes WTO Members to Resolve Judges' Appointment Issue in Appellate Body, THE ECONOMIC TIMES, Jan. 15, 2019, https://economictimes.indiatimes.com/news/economy/foreign-trade/india-asks-wtomembers-to-resolve-judges-appointment-issue-in-appellate-

body/articleshow/67546242.cms.

36 Section 301 is a provision of the Trade Act of 1974 as amended that allows the US government to impose trade sanctions on other countries on a unilateral basis. See 19 U.S.C. \2411 (2012) et seq.

${ }^{37}$ Even before the WTO came into force, the use of regular Section 301 authority to impose a tariff was rare. 
thefts from US company computer networks. ${ }^{38}$ The President's supporting Memorandum does not explain whether or why any of these alleged Chinese actions is a WTO violation. ${ }^{39}$ In March 2018, the US began a WTO dispute against China pursuant to the TRIPS Agreement regarding patent enforcement and mandatory technology terms, and a DS542 panel was appointed in January 2019. Other than two cases on agriculture lodged in 2017, the US has not brought WTO cases against any of the other alleged misdeeds by China. ${ }^{40}$

Under the Section 301 authority, the Trump Administration is currently imposing tariffs of $10 \%$ against Chinese goods worth $\$ 200$ billion and tariffs at $25 \%$ against goods worth $\$ 50$ billion. The Administration has threatened to raise those tariffs to $25 \%$ and expand the quantity of imports sanctioned by US tariffs by another $\$ 500$ billion. ${ }^{41}$ China retaliated against the $10 \%$ tariffs and pledged to retaliate against the US escalation.

In December 2018, the US and Chinese governments reached a tariff truce wherein both sides agreed to hold off on imposing additional tariffs. ${ }^{42}$ The aggressive actions by the US violate WTO law. The new tariffs are a violation of the US tariff bindings in GAT'T Article II, regardless of whether the accusations against China are true and if true, regardless of whether China's actions violate WTO rules. To the extent that the US claims that Section 301 is being used against WTO-illegal actions by China,

\footnotetext{
38 Presidential Memorandum on the Actions by the United States Related to the Section 301 Investigation, THE White House (Mar. 22, 2018), https://www.whitehouse.gov/presidentialactions/presidential-memorandum-actions-united-states-related-section-301-investigation/. ${ }^{39}$ Various commentators have suggested that if particular allegations against China are true, then such behaviour by China could violate regular WTO rules or China's accession agreement. Analysing whether a cause of action would exist for stipulated facts is beyond the scope of this article. If the Trump Administration believes that China is violating the WTO, then the complaining government has the burden of making a legal argument and so far, as far as this author has seen, no such legal memorandum exists. The absence of legal analysis in this instance probably stems from the fact that the use of unilateral US Section 301 sanctioning authority does not require a finding by the USTR that China is violating W'TO law.

40 The Trump Administration did initiate a case in July 2018 against China's retaliation in response to the illegal Section 301 tariffs imposed by the United States.

41 Jenny Leonard \& Jennifer Jacobs, U.S. Reportedly Planning More Tariffs Against China if November Talks Fail, BLOOMBERG, Oct. 29, 2018, http://time.com/5438501/us-tariffschina-november-talks/.

42 Jason Lemon, Trump Gives in to China and Agrees to Suspend Adding New Tariffs, NewsweEK, Dec. 2, 2018, 10:55 AM, https://www.newsweek.com/trump-gives-china-agrees-suspendadding-new-tariffs-1240308; Trump's China Trade Truce, WALL ST. J. OPINION (Dec. 2, 2018, 5:47 PM), https://www.wsj.com/articles/trumps-china-trade-truce-1543790868.
} 
the US' response violates the constitutional rule in DSU Article 23 that prohibits WTO Members from seeking to unilaterally enforce WTO rights. To the author's knowledge, the Trump Administration has not offered any WTO law defence for its Section 301 actions. Although the Trump Administration's actions under Section 301 are not explicitly based on any claim that China is violating international trade rules, even if it were to make that legal argument, its actions would also violate the promises made by the US to the WTO panel in 1999 in the US - Section 301 dispute. ${ }^{43}$ The Section 301 panel noted that it was accepting the good faith of the US government's promises to not invoke Section 301 in a W'TO-inconsistent way, but should the United States ever renege on that commitment, the finding by that panel that Section 301 was in conformity with WTO law "would no longer be warranted." 44 Thus, not only are the Trump Administration's actions pursuant to Section 301 a violation of the W'TO, these actions have also rendered the US Section 301 law as such a violation of the WTO. In addition, the new farm aid being dispensed by the Trump Administration to domestic farms hurt in the trade war ${ }^{45}$ may violate US commitments under the W'TO's Agreement on Agriculture.

As many observers have noted, Chinas industrial policies and regulation of foreign investors may violate some WTO-plus commitments in China's Accession Protocol. ${ }^{46}$ But so far, no WTO Member has brought such a case against China. Given the Trump Administration's repeated claims that China is not playing by the rules, the unwillingness of the Trump Administration to test its claims before a W'TO tribunal suggests that it doubts that its claims against China have legal or factual merit.

Most close observers of the WTO believe that the transnational legal process in the WTO would be capable of investigating China's actions and holding China

43 Panel Report, United States - Sections 301-310 of the Trade Act 1974, WTO Doc. WT/DS152/R (Dec. 22, 2000).

${ }^{44}$ Id. $\ 7.136$.

${ }^{45}$ Alan Rappeport, $A \$ 12$ Billion Program to Help Farmers Stung by Trump’s Trade War Has Aided Few, N.Y. TIMES, Nov. 19, 2018, https://www.nytimes.com/2018/11/19/us/politics/farming-trump-trade-war.html.

46 See, e.g., Simon Lester, New EU Consultations Request on (Alleged) Chinese Forced Technology

Transfer, INT'L ECON. L. \& POL’Y BLOG (Dec. 20, 2018), https://worldtradelaw.typepad.com/ielpblog/2018/12/new-eu-consultations-request-onalleged-chinese-forced-technology-transfer.html; Simon Lester, Forced Technology Transfer and the WTO, INT'L ECON. L. \& POL'Y BLOG (Mar. 29, 2018), https://worldtradelaw.typepad.com/ielpblog/2018/03/forced-technology-transfer-andthe-wto.html. 
accountable to the international rule of law. ${ }^{47}$ Moreover, winning WTO cases against China is hardly fruitless as China's compliance record in WTO proceedings is seemingly at least as good as the US record of compliance. While punitive US trade sanctions have apparently resulted in China's agreement to enter into new negotiations as of December 2018, less aggressive tactics could have been equally (or more) effective, particularly if the US had dynamically teamed up with allied governments.

During his first few days in the White House, President Trump imposed two safeguards under Section 201 of the Trade Act of 1974 on imports of solar cells and modules and on residential washing machines. ${ }^{48}$ For solar panels, the protection provided was a 30\% tariff and for washing machines, a complex tariff-rate quota was imposed of up to a $50 \%$ tariff. The safeguard on residential washers is clearly a violation of the GATT, as one of the preconditions for WTO-legality, an analysis of unforeseen developments by the investigating authority, was not undertaken by the US International Trade Commission. ${ }^{49}$

The other major tariff actions taken by the Trump Administration have been to employ Section 232 to impose tariffs on steel and aluminium. ${ }^{50}$ Although Section 232, with its title 'Safeguarding National Security' was enacted in 1962, no US President before Trump had used Section 232 to impose worldwide tariffs on a product. The rationale behind Section 232 is that excessive imports of a product can inhibit US national security by taking market share from an import-competing domestic industry, thereby rendering the domestic industry less financially sustainable. This logic of Section 232 is purely protectionist. Before Trump, previous US Administrations had rejected entreaties to improve US national security by reducing the availability of imports of important products. Trump's Section 232 action imposed $25 \%$ tariffs on steel and $10 \%$ tariffs on aluminium. These tariffs are

\footnotetext{
${ }^{47}$ See, e.g., James Bacchus, Simon Lester \& Huan Zhu, Disciplining China's Trade Practices at the WTO: How WTO Complaints Can Help Make China More Market-Oriented (Cato Institute Policy Analysis Number 856, Nov. 15, 2018), https://www.cato.org/publications/policyanalysis/disciplining-chinas-trade-practices-wto-how-wto-complaints-can-help.

48 See Remarks by President Trump at Signing of a Presidential Memorandum Targeting China's Economic Aggression, THE White HOuse (Mar. 22, 2018, 12:45 PM), https://www.whitehouse.gov/briefings-statements/remarks-president-trump-signingsection-201-actions/; Executive Office of the President of the United States, Section 201 Cases: Imported Large Residential Washing Machines and Imported Solar Cells and Modules, https://ustr.gov/sites/default/files/files/Press/fs/201\%20Cases $\% 20$ Fact $\% 20$ Sheet.pdf; 19 U.S.C. $\$ 2251$ (2012).

49 See GATT Art. XIX. U.S. International Trade Commission, Large Residential Washers, TA-201-076, Dec. 2017.

5019 U.S.C. $\int 1862$ (2012), which codifies Section 232 of the Trade Expansion Act, 1962.
} 
added to any existing tariffs; for steel, the pre-existing duty rates were zero. Subsequently, in a pique with Turkey, President Trump doubled the tariff on Turkish steel to $50 \% .^{51}$

The goal of the steel tariffs is to increase capacity utilisation in the steel sector to $80 \% .52$ Since the steel tariffs were imposed, capacity utilisation has increased from $73 \%$ to almost $80 \% .^{53}$ Imports have fallen by $27 \% .{ }^{54}$ To reduce the burden of its actions on US commerce, the Trump Administration has provided an exemption system to remove the new tariffs on particular products at the request of special interest petitioners. The Administration has also provided exemptions for four countries - Argentina, Australia, Brazil and South Korea. Any exemption, of course, contradicts the ostensible purpose of Section 232 which is to increase the domestic content of US steel consumption. The steel (and aluminium) tariffs violate GATT rules. Because they abridge US tariff bindings, the Section 232 tariffs violate GATT Article II. Because the Administration has provided a steel tariff exemption for four countries only, the remaining discriminatory tariffs also violate GATT Article I.

Defenders of the steel and aluminium tariffs claim that these tariffs cannot be ruled a WTO violation by the DSB because of the GAT'T's broad provision for 'Security Exceptions' in Article XXI. That Article has no WTO case law but an interpretation based on its ordinary meaning, context, and purpose would suggest that any utilisation of the Article XXI would have to meet the conditions under the Article XXI(b)(iii) defence which can only be invoked "in time of war or other emergency in international relations." If examined by a WTO panel, the US would have the burden of proving that 2018-19 is a time of war or emergency affecting steel exporting countries. In response to these challenges to WTO legality, supporters of Section 232 tariffs assert that a panel could never consider any of these arguments because WTO panels do not have jurisdiction when a defending government invokes Article XXI. For example, the US Senate Republican Policy Committee argues that "[a]ll national security tariffs fall outside of the World Trade

\footnotetext{
${ }^{51}$ Jim Tankersley, Ana Swanson \& Matt Phillips, Trump Hits Turkey When It's Down, Doubling Tariffs, N.Y. TIMES, Aug. 10, 2018), https://www.nytimes.com/2018/08/10/us/politics/trump-turkey-tariffs-currency.html. 52 U.S. DeP'T OF COMMERCE, The EFFECTS OF Imports OF STEEL ON NATIONAL SECURITY, at 4 (Jan. 11, 2018), https://www.commerce.gov/sites/default/files/the_effect_of_imports_of_steel_on_the_ national_security_-_with_redactions_-_20180111.pdf.

53 Int'l Trade Admin., SteEl Industry EXeCutive Summary: January 2019, at 10, https://enforcement.trade.gov/steel/license/documents/execsumm.pdf (last visited Feb. 23, 2019).

54 See id. at 2.
} 
Organization's jurisdiction and cannot be reviewed". 55 The Office of the US Trade Representative (USTR) has argued that "tariffs imposed pursuant to Section 232 are issues of national security not susceptible to review or capable of resolution by WTO dispute settlement" 56

The imposition of Section 232 tariffs and the invocation of GAT'T Article XXI by the US as a defence has provoked a dilemma at the WTO because if every WTO member could use Article XXI to justify any protectionist measure, then such an open-ended exception would swallow up all of the rules that have been negotiated since 1947. ${ }^{57}$ Recently, the US Ambassador to the WTO warned the DSB that "if the WTO were to undertake to review an invocation of Article XXI, this would undermine the legitimacy of the WTO's dispute settlement system and even the viability of the WTO as a whole". ${ }^{58}$

Of course, the opposite conclusion is more likely to be true. Were a WTO panel to dismiss the current complaints by China, European Union, Canada, Mexico, Norway, Russia, and Turkey over Section 232 tariffs on steel and aluminium, it would call into question the viability of the WTO's rules and the dispute settlement system. WTO Director-General, Roberto Azevêdo, has recently warned that the pending WTO challenge to Section 232 tariffs is 'risky'. ${ }^{59}$ But the risk in this instance is caused by the US, and the best way to prevent that risk is by clarifying WTO law as to whether the US' actions violate the GAT'T.

In another assault on the rule of law in general and China in particular, the US has refused to acknowledge and comply with the requirements in China's WTO Accession Agreement regarding the use of trade remedies. When it joined the W'TO, China agreed to an onerous, incumbent WTO-minus law regime wherein importing

55 See National Security Tariffs: Section 232, SENATE RPC (June 26, 2018), https://www.rpc.senate.gov/policy-papers/national-security-tariffs-section-232.

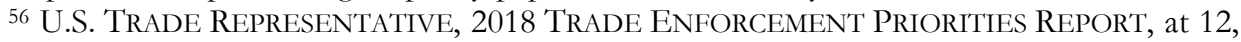
https://ustr.gov/sites/default/files/files/Press/Reports/2018/USTR\%202018\%20Enforc ement\%20Priorities\%20Report.pdf (last visited Feb. 26, 2019).

57 Ana Swanson \& Jack Ewing, Trump's National Security Claim for Tariffs Sets Off Crisis at W.T.O., N.Y. TIMES, Aug. 2018, https://www.nytimes.com/2018/08/12/us/politics/trumps-tariffs-foster-crisis-at-thewto.html.

${ }^{58}$ Hannah Monicken, U.S.: Ruling on 232 Tariffs Would Undermine 'Viability' of WTO, WORLD TRADE ONLINE (Oct. 29, 2018, 6:04 PM), https://insidetrade.com/daily-news/us-ruling232-tariffs-would-undermine-viability-wto.

59 Azevêdo: Challenging U.S. 232 Tariffs at WTO is Risky', WorLd Trade OnLINE (Dec. 4, 2018, 3:30 PM), https://insidetrade.com/daily-news/azev\%C3\%AAdo-challenging-us-232tariffs-wto- $\% \mathrm{E} 2 \% 80 \% 98$ risky $\% \mathrm{E} 2 \% 80 \% 99$-strategy. 
governments were given almost unfettered discretion to ignore prices in China's market in calculating antidumping duties. ${ }^{60}$ But this (mis)treatment was allowed only for fifteen years and that period terminated in December 2016. After that, according to the China Protocol, the new obligation on the US and other WTO Members is that China is entitled to its market prices being used in antidumping proceedings if Chinese "producers under investigation can clearly show that market economy conditions prevail in the industry ... with regard to the manufacture, production and sale of that product." ${ }_{11}$ This is an objective standard that needs to be applied by antidumping authorities on an industry by industry basis. ${ }^{62}$

Unfortunately, US antidumping authorities are not currently applying the proper legal test (for that matter, European authorities are not doing so either, and China has brought a W'TO case against the EU). Although the Trump Administration has not offered any explanation as to why the Accession Protocol does not impose a new objective standard, it argues that "China's position" is that "importing Members must ignore the extensive distortion in China's economy and grant China special rights and privileges under the anti-dumping rules that are not accorded to any other Member." 63 Of course, that has never been China's position. The W'TO-China Protocol does not require that importing Members ignore distortions in China's prices, only that importing Members give Chinese producers the right to show that market conditions prevail in the subject exporting industry (even if they do not prevail in other industries). Currently, USDOC procedures do not give that right to Chinese respondents in an antidumping case. ${ }^{64}$

Although Trump has threatened to withdraw the United States from the W'TO and the NAFTA, the only multilateral trade agreement that Trump followed through on

${ }^{60}$ Accession of the People's Republic of China, WT/L/432, Protocol, Nov. 23, 2001, 9 15(a)(ii).

61 Id. $\ 15(\mathrm{a})(\mathrm{i})$.

62 See Ritwik Bhattacharya, Three Viempoints on China's Non-Market Economy Status, 9(2) Trade L. \& DEV. 188 (2017), calling for a shifting burden of proof standard.

63 Supra note 29, at 33. In my view, China's Protocol after 2016 does impose new disciplines on antidumping proceedings against China that may not apply to other WTO Members, but these were rules agreed to by WTO Members as part of the Chinese accession negotiations. 64 U.S. Dep't of Commerce, Public Document E\&C VI: MJH/TB, https://www.ustradeblog.com/files/2017/10/Chinas-NME-Status-Memo.pdf (last visited Feb. 23, 2019). 
his threats to withdraw from, ${ }^{65}$ has been the TPP where Trump withdrew the US during the initial days of his Presidency. Despite the US withdrawal, the TPP came into force in late 2018 without the US, and the new agreement provides cutting-edge multilateral trade governance for many countries in the Pacific region. ${ }^{66}$ The new agreement, called the Comprehensive and Progressive Agreement for Trans-Pacific Partnership, is valuable for its own governance benefits and also as a symbol of how multilateral trade reforms can go forward without the US.

In summary, the Trump Administration appears to reject a central normative role for international law in governing US policy. ${ }^{67}$ This demotion of law can be seen in the Administration's National Security Strategy published in December 2017. While not a full-throated denunciation of international law, the Administration took a selfcontradictory stance by declaring that " $[t]$ he United States supports the peaceful resolution of disputes under international law but will use all of its instruments of power to defend US interests" 68 . Should the US use power in an illegal way to promote its own view of its national interest, it would forgo the foundation of international normativity, which is that you can only ask other countries to follow international law if you have been willing to do so yourself. A central mistake of the Trump Administration has been to further degrade the US' reputation of being a law-abiding nation. Besides squandering influence on other countries, the Trump Administration's trade actions are also a threat to the integrity of international economic law.

If international economic law is inadequate, then the optimal response for nations is to work together internationally to rewrite conventional international law so that it better meets the needs of the world economy. Nationalist self-help actions cannot be a substitute for better international rules. At best, unilateral actions can occasionally serve to catalyse governments to improve international law, but such non-cooperative techniques can only work if used sparingly and with an eye toward the end game of launching new negotiations. In the author's view, the unilateral trade

65 Trump Executive Order Pulls out of TPP Trade Deal, BBC NEWs (Jan. 24, 2017), https://www.bbc.com/news/world-us-canada-38721056. To his credit, President Trump reversed the withdrawal of the United States from the Bureau of International Expositions (BIE) that had occurred in 2001. See Steve Charnovitz, Why the International Exbibitions Bureau Should Choose Minneapolis for Global Expo 2023 (GWU Law School Public Law Research Paper No. 2017-82, Oct. 2017), https://papers.ssrn.com/sol3/papers.cfm?abstract_id=3053623.

${ }^{66}$ For example, Chapter 17 of the TPP provides new disciplines for state-owned enterprises and designated monopolies.

${ }^{67}$ See generally Harold HonguU KoH, THE TRUMP ADMINISTRATION AND INTERNATIONAL LAW (2018).

68 National Security Strategy of the United States, THE WHITE House, at 41 (Dec. 2017), https://www.whitehouse.gov/wp-content/uploads/2017/12/NSS-Final-12-18-2017-

0905.pdf (last visited Feb. 26, 2019). 
actions of the Trump Administration have not been sufficiently focused or justified to produce any long-term constructive effect. Rather than being a law breaker, the Trump Administration should have positioned the US as a law maker by offering a detailed proposal to improve the operation of the DSU. One much needed reform would be to eliminate the possibility of objecting to a WTO panel (see DSU Article 6.1) which has the effect of delaying the requested WTO panel for a few weeks until the next DSB meeting.

\section{RETREAT FROM FREE TRADE}

The theory of import protection is that human freedom to engage in the voluntary, mutually beneficial, and legal exchange of goods and services across borders will lead to outcomes that can be improved upon by government-imposed restrictions aimed at raising aggregate social welfare. No one questions that when market failures exist, government intervention can improve outcomes. But the theory of import protection is not predicated on the existence of market failures. Instead, the concept is that free trade without tariffs or quotas can make an economy as a whole worse off than if trade never occurred. Since individuals trade only when trade will make them individually better off, the justification for protection is not deontological but rather utilitarian. So any proof for the theory of protection would need to come from simulations or real world experiences that show trade reducing aggregate wealth rather than creating it.

Another way of explaining the theory is that governments should manage trade as a component of industrial policy by picking the winning industries that will generate the most income and jobs for the national economy. The clearest refutation of this theory was the axiom offered decades ago that while governments are not skilful at selecting winners, losers are skilful at getting selected by governments. ${ }^{69}$ In other words, various causes of government failure will inevitably mean that special interests would control the details of a government industrial policy, and the government will end up supporting industries whose collective output and job creation will be far less optimal than what the unsupervised market would yield. This pathology is not trade-related. Even in a closed economy, the gainers from government intervention will generally never make enough income to compensate the losers. Thus, if an industrial policy does not generate enough surplus income to compensate the industries that are not being favoured by the government, then the industrial policy is merely a transfer of income not a way to expand the income that the market alone could produce.

${ }^{69} \mathrm{I}$ do not know this origin of this axiom, but the first person I heard it from was Alfred Reifman in the 1990s. For one version of it in 2008, see Sinclair Davidson, Governments Cannot Pick Winners but Losers Can Pick Governments, ON LINE OPINION (June 17, 2008), http:/ / www.onlineopinion.com.au/view.asp?article $=7496$. 
Although shunning imports is not inherent to an industrial policy, in practice, industrial policies tend to be mercantilist in orientation by promoting exports over imports and sheltering favoured industries from import competition. Even if there were some magic by which governments could create wealth by wise resource allocation, in a world economy with other competing economies, the industrial policy choices of one government will be vulnerable to the industrial counterpolicies of other governments. For example, if all major countries choose to subsidise and protect their steel industries, the amount of steel trade will fall (even to zero) and the cost of saving or creating an additional steel job will rise.

Some may see virtue in such national economic self-sufficiency. ${ }^{70}$ The problem with rejecting economic interdependence in favour of economic independence is that there is no obvious geographic unit that should be self-contained. The family might be the most logical unit but that approach was abandoned by humanity in the Stone Age. Should each city be self-sufficient? Clearly, if a city like Jodhpur separated its economy from the rest of Rajasthan, India, and the Earth, the residents of Jodhpur would not be better off. Sometimes, mixing patriotism with autarky, the nation state is pointed to as the proper unit of self-sufficiency. But while that idea may seem attractive to some in the largest countries, it will be unattractive to the smallest countries and to producers and consumers in any country that want to pursue their self-interest by participating in the world economy.

The virtue of trade and free trade is not usually attacked from the front but rather from the rear with the argument that free trade is only optimal if it is fair trade. Yet, fair trade is an "empty notion", ${ }^{71}$ as the eminent trade theorist Jagdish Bhagwati has repeatedly pointed out, because fairness is a relative concept in the eyes of the beholder. Nevertheless, the world trading system has always bought into the unfairness concept, and the system allows governments to impose tariffs on imports that are dumped or subsidised under prescribed circumstances and to impose import bans to enforce domestic unfair trade laws, for example, relating to antitrust, customs, deceptive practices, and intellectual property rights. ${ }^{72}$ But not every claim of fairness is recognised by the trading system as a justification for imposing a tariff to level the playing field. ${ }^{73}$ Many domestic policies, such as environmental or labour

\footnotetext{
${ }^{70}$ Indeed, Keynes in 1933 did. John Maynard Keynes, National Self-Sufficiency, 22(4) YALE REV. 755 (June 1933), https://www.mtholyoke.edu/acad/intrel/interwar/keynes.htm (last visited Feb. 26, 2019). ${ }^{71}$ Jagdish Bhagwati, The Folly of Fair Trade, WALL ST. J., Mar. 11, 1999, at 22.

${ }_{72}$ GATT Arts. VI and the Antidumping Agreement, GATT Art. XX(d), and the SCM Agreement, Part V.

73 See Jagdish Bhagwati \& Robert E. Hudec, Free Trade and Harmonization (1996).
} 
standards, are not considered by WTO law to be a basis for imposing eco-tariffs or social dumping duties.

The maximum benefits of global free trade will ensue when all governments fully cooperate. When a government fails to cooperate by subsidising exports, the W'TO provides a corrective solution of imposing a countervailing duty and a right of action in WTO dispute settlement. When a trading partner fails to cooperate by imposing prohibited tariffs or non-tariff barriers, there is a right of action in WTO dispute settlement. But when a trading partner fails to reciprocate by not lowering tariffs in the first place or by indirectly preventing trade or investment, there may not be a right of action in WTO law.

Trade economists have always recognised the problem of countries that seek to free ride on the trading system by refraining from reciprocally opening their own markets. Whether Country A should use retaliatory tariffs against Country B to get Country B to open its market has long been debated. In 1776, in The Wealth of Nations, Adam Smith posited that: "There may be good policy in retaliations of this kind, when there is a probability that they will procure the repeal of the high duties or prohibitions complained of. The recovery of a great foreign market will generally more than compensate the transitory inconveniency of paying dearer during a short time for some sorts of goods."74

Smith's insight has been explored in political economy since the $18^{\text {th }}$ century, but to my knowledge, there is no generally accepted way to operationalise his idea that closing markets can reliably lead to wider market opening. Section 301, enacted in 1974, was intended to use economic leverage to open up foreign markets, but the idea appeared in US law as early as 1916, though never used. ${ }^{75}$

In any event, using Section 301 was illegal under the GATT even when it was enacted in 1974. Section 301 of US trade law authorises the USTR to use tariff 'retaliation' as a way to open up foreign markets through bilateral negotiations. Proponents of a Section 301 tariff generally do not make the facetious argument that such a tariff is legal under WTO rules and generally do not argue that Section 301 provides a good model for other countries to adopt and apply against the US. Rather, proponents avoid discussions of those pragmatic topics altogether and focus instead on the technical aspects of determining what foreign country should be targeted, what specific industries should be targeted, and how high the tariffs should be. Another topic not mentioned in polite Section 301 conversations is the cost of

\footnotetext{
74 AdAM SMith, ON Systems of Political ECONOMY, ch. II, https://www.marxists.org/reference/archive/smith-adam/works/wealth-of-

nations/book04/ch02.htm.

75 See, e.g., 15 U.S.C. $\int 75$ (2012) titled Retaliation Against Country Prohibiting Importations.
} 
Section 301 tariffs on the US economy. Despite the broad list of legislative factors to be considered in applying US tariff retaliation, Section 301 is mute on whether the USTR's calculus should consider the potential costs to the US domestic economy of foreign countermeasures imposed in response to Section 301 tariffs.

US trade policy has never fully embraced free trade, but in the latter half of the $20^{\text {th }}$ century, the US was a leader in promoting international pacts to liberalise trade and remove barriers to more open markets. ${ }^{76}$ The Clinton Administration gained US Congressional approval for the NAFTA and the WTO, and the Bush 43 Administration negotiated and gained Congressional approval for several free trade agreements. The US also strongly supported accessions to the W'TO Agreement to render its rules more universal and to assist non-market economies in making a transition to free market principles.

By the late 1990s, a resistance to deepening economic globalisation began to set in. The efforts at the Organization for Economic Co-operation and Development (OECD) to achieve a Multilateral Agreement on Investment (MAI) failed in 1998. The efforts at the WTO to make progress toward launching new multilateral negotiations sputtered at Seattle in 1999 but succeeded in a window of goodwill following the September 11 attacks.

The W'TO launched its ambitious Doha Round in November 2001, but the decision to group all negotiations into a single undertaking required an intensive political momentum that did not ensue. When the US Congress approved a new trade negotiating authority in 2002, one of the objectives included was "to preserve the ability of the United States to enforce rigorously its trade laws, including the antidumping, countervailing duty and safeguard laws". ${ }^{77}$ Since some aspects of these laws and their implementation had already been found to violate WTO rules, ${ }^{78}$ this negotiating stance stuck a dagger in the hopes of many developing countries that the most abusive US trade remedy practices might be outlawed in the Doha negotiations.

By the late 1990s, the investor protection provisions in the NAFTA had already come under intense criticism by civil society because foreign investors were to be protected by minimum international standards. The 2002 US trade promotion authority sought to prevent such discipline in the future by reducing the intended

\footnotetext{
76 See Frederick W. Smith, How Trade Made America Great, WALL ST. J., Mar. 26-27, 2016, at A9. See also Daniel W. Drezner, U.S. Trade Strategy: Free Verus Fair (2006).

7719 U.S.C. $\int 3802(\mathrm{~b})(14)$ (2012).

${ }^{78}$ E.g., Appellate Body Report, United States - Anti-Dumping Act of 1916, WTO Doc. WT/DS136, 162/AB/R (adopted Sept. 26, 2000).
} 
protection of foreign investors in the US to the level of substantive protection offered domestically to US investors. ${ }^{79}$ Of course, the idea of trimming back foreign investors' rights to the level granted to domestic investors has deep historical roots (e.g., the Calvo Doctrine), and this parochial approach will necessarily weaken investment protection. Moreover, such an inward-looking orientation rules out any idealistic hopes of supplementing multi-national investor rights with multi-national enterprise obligations.

\section{A. The Obama Administration}

Protectionists gained an enabler when President Obama was elected. Obama had campaigned against the NAFTA and promised to renegotiate it, ${ }^{80}$ but in his eight years in office, he omitted to do so. By allowing criticisms of the NAFTA to go unaddressed, and then by allowing the NAFTA to further deteriorate in public opinion during his Presidency, Obama's standpatism set the stage for deepening US public opposition to the NAFTA and to free trade being a core part of Donald Trump's platform in the 2016 US elections. When the Obama Administration signed the TPP in February 2016, it actually had the chutzpah to characterise the TPP as a renegotiated NAFTA because Mexico and Canada were to be part of the TPP. ${ }^{81}$ But that strange argument demonstrated not only political ineptitude, because the Obama Administration had no practical plan for getting the US Congress to approve the TPP, but also a lack of vision in failing to appreciate the NAFTA as a North American integration agreement that could be a stepping stone for enhancing cooperation across a wide range of fields.

The three new FTAs that had been negotiated at the end of the Bush Administration - the Columbia, Korea and Panama FTAs - were left on the shelf by the Obama Administration in 2009 and were not sent to and approved by the Congress until 2011. The US-Korea FTA (KORUS) had a particularly arduous path because the Obama Administration insisted on reopening and renegotiating it. The key changes were to delay until 2019 the reduction in America's 25\% tariff on light trucks and to delay other mutual tariff reductions for autos. The Obama Administration also demanded that Korea's agreement grant a special exemption for US cars from Korea's stringent environmental, fuel economy and automobile safety

\footnotetext{
7919 U.S.C. \$3802(b)(3) (2012).

80 Alexander Lane, Obama's Been Critical of NAFTA, POLITIFACT (Oct. 15, 2008), https://www.politifact.com/truth-o-meter/statements/2008/oct/15/johnmccain/obamas-been-critical-of-nafta/.

81 See, e.g., The Trans-Pacific Partnership, https://ustr.gov/sites/default/files/TPP-ProtectingWorkers-Fact-Sheet.pdf.
} 
standards. ${ }^{82}$ These latter provisions were particularly cynical as they gave credence to the long-time civic society claims that trade agreements would derogate from domestic environmental and safety standards.

The biggest failures of the Obama Administration on trade were not its actions but rather its inactions. Although President Obama often talked about his support for trade as an instrument of US job creation, his Administration did little to connect trade to a broader plan for pro-growth and pro-competitiveness policies that could improve the standard of living for ordinary Americans. For example, the Obama Administration failed to do much to improve trade adjustment assistance and other programs designed to help workers, companies, and communities recover from the negative effects of foreign competition. ${ }^{83}$ The Administration did champion greater access to health care, but there were no equally comprehensive efforts to boost access to worker training or to upgrade America's decaying infrastructure. The Obama Administration also missed an opportunity to work with the Congress, the States, and the private and civic sector to enhance political support for international trade, the NAFTA, and the W'TO. By 2010, the signs were clear that support for trade was fraying around the country, but no trade leadership ensued from Obama.

Although President Obama never threatened to quit the WTO, his Administration in practice disengaged the US from the WTO. The top priority of the WTO during the Obama years (2009-17) was the completion of the Doha trade negotiations, but the Obama Administration showed little interest. While most WTO governments understood the Doha Round as being focused on improving the trade position of developing countries, ${ }^{84}$ the Obama Administration never supported this conception and was unwilling to put aside US mercantilist objectives in favour of giving the W'TO a victory by allowing it to deliver a package of tangible economic benefits for developing countries. The Administration's romance with the TPP during Obama's second term was a manifestation of its deepening alienation from the WTO. Yet, even when the second Obama Administration began to engage in serious negotiations for the TPP (and to a lesser extent for a Trans-Atlantic Free Trade and

82 Jeffrey J. Schott, KORUS FTA 2.0: Assessing the Changes, PETERSON INST. FOR INT'L ECON., (Dec. 2010), https://piie.com/sites/default/files/publications/pb/pb10-28.pdf (last visited Feb. 26, 2019).

${ }^{83}$ Steve Charnovitz, USTR Should Devote More Attention to Worker Issues, INT'L ECON. L. \& POL'Y BLOG July 23, 2009), https://worldtradelaw.typepad.com/ielpblog/2009/07/charnovitz-ustr-should-devotemore-attention-to-worker-issues.html.

84 See The Doha Round, WORLD TRADE ORG., https://www.wto.org/english/tratop_e/dda_e/dda_e ("The Round is also known semiofficially as the Doha Development Agenda as a fundamental objective is to improve the trading prospects of developing countries.”). 
Investment Agreement), the prospect of these trade talks was jeopardised by the lack of transparency and by refusing to provide for meaningful participation by civic and business associations.

\section{B. The Trump Administration}

With a few notable exceptions, the rhetorical support for free trade by President Obama has been abandoned by President Trump. For Trump, international trade is an albatross for the American economy that can be measured by the trade deficit. As Trump explained in his Inaugural Address: "We must protect our borders from the ravages of other countries making our products, stealing our companies and destroying our jobs. Protection will lead to great prosperity and strength" (emphasis added). ${ }^{85}$

For protection, the instrument of choice for Trump is the tariff. Trump claims that "[t]ariffs will make our country much richer than it is today." 86 This assertion is easy to debunk because if tariffs could make any country richer, then all countries would be very rich indeed because tariffs are so easy to implement.

Trump's ability to unilaterally raise tariffs is unusual because in most countries, tariffs require legislative action to change. But US law gives the President extraordinary executive authority to erect tariff walls without any judicial review to consider whether sufficient evidence has been marshalled to show that the benefits exceed the costs. With regard to immigration, Trump's effort to erect a wall at the southern border have been stymied in the courts and the Congress. But so far no such checks exist for Trump's executive authorities on tariffs which, in many instances, set no temporal or numerical limits. As a result, Trump relishes his unchaperoned authority to reverse globalisation by imposing tariffs. Indeed, Trump's tariff-writing authority has boosted his self-identity. Indeed, in early December 2018, Trump boasted, "I am a Tariff Man ... It will always be the best way to max out our economic power." 87

85 The Inangural Address, THE White House (Jan. 20, 2017), https://www.whitehouse.gov/briefings-statements/the-inaugural-address/. Note the hostility to the idea that the making of products for the US market might be shifted to other countries.

86 John Brinkley, Trump Loves Tariffs, But No One Else Does, FOrBES, Aug. 8, 2018, https://www.forbes.com/sites/johnbrinkley/2018/08/08/trump-loves-tariffs-but-no-oneelse-does/\#6c538d60662e.

87 The Editorial Board, I Am a Tariff Man', WALL ST. J., Dec. 5, 2018, at A18, https://www.wsj.com/articles/i-am-a-tariff-man-1543965558. 
Trump's trade policy is predicated on his view that past US trade policy has weakened the US economy. Speaking at the United Nations (UN) in 2018, Trump declared:

"We believe that trade must be fair and reciprocal. The United States will not be taken advantage of any longer. For decades, the United States opened its economythe largest, by far, on Earth - with few conditions. We allowed foreign goods from all over the world to flow freely across our borders. Yet, other countries did not grant us fair and reciprocal access to their markets in return. Even worse, some countries abused their openness to dump their products, subsidize their goods, target our industries and manipulate their currencies to gain unfair advantage over our country." 88

Trump also believes that trade agreements have been bad for the US. In his address to the UN in 2017, Trump instructed world leaders that, "For too long, the American people were told that mammoth multinational trade deals, unaccountable international tribunals, and powerful global bureaucracies were the best way to promote their success. But as those promises flowed, millions of jobs vanished and thousands of factories disappeared." 89

The 'unaccountable' trade tribunal that Trump was referring to is the WTO Appellate Body which has regularly and properly ruled against the US government. Trump never acknowledges that the US is a major violator of WTO law and has many import barriers unfair to other countries, particularly developing countries. ${ }^{90}$ The multilateral WTO has been a constant target of complaints by Trump, and he has repeatedly threatened to pull the US out of the W'TO. ${ }^{91}$ Trump's top complaint

${ }^{88}$ Remarks by President Trump to the $73^{\text {rd }}$ Session of the United Nations General Assembly, THE WHITE HOUSE (Sept. 25, 2018), https://www.whitehouse.gov/briefings-statements/remarkspresident-trump-73rd-session-united-nations-general-assembly-new-york-ny/.

89 Remarks by President Trump to the 72nd Session of the United Nations General Assembly, THE White HOusE (Sep. 19, 2017), https://www.whitehouse.gov/briefingsstatements/remarks-president-trump-72nd-session-united-nations-general-assembly/.

90 See Laura Baughman, Five Myths About Imports, WALL ST. J., May 20, 2014, at A11; Simon Lester, American Trade Hypocrisy, INT'L ECON., Fall 2018, at 44.

${ }^{91}$ Damien Paletta \& Ana Swanson, Trump Suggests Ignoring World Trade Organization in Major Policy Shift, WASH. POST, Mar. 1, 2017, https:/ / www.washingtonpost.com; Trump Threatens to Pull US out of World Trade Organization, BBC, Aug. 31, 2018, https://www.bbc.com/news/world-us-canada-45364150; Simon Johnson, Trump's War Against the WTO, Project Syndicate, Nov. 30, 2018, https://www.projectsyndicate.org/commentary/trump-war-against-world-trade-organization-by-simonjohnson-2018-11. 
about the WTO is that it is 'unfair' to the US.92 There is an interesting parallel between his criticisms of the trade regime and his criticism of the climate regime. While announcing in 2017 that he would withdraw the US government from the Paris Agreement, Trump explained: "The Paris Climate Accord is simply the latest example of Washington entering into an agreement that disadvantages the United States to the exclusive benefit of other countries, leaving American workers-who I love - and taxpayers to absorb the cost in terms of lost jobs, lower wages, shuttered factories and vastly diminished economic production." 93

Part II above discusses the impact of Trump's anti-W'TO actions on international law. Here, one should note how deleterious his threats to quit the WTO are to the "security and predictability" of world trade which is one of the purposes of WTO rules. ${ }^{94}$ The Trump Administration's indifference was one of the reasons why the 2017 WTO Buenos Aires Ministerial failed to achieve any outcome. ${ }^{95}$

Besides the WTO, Trump has sought to capsize regional trade agreements. In his campaign, Trump called the TPP "another disaster done and pushed by special interests who want to rape our country", 96 and, as President, he quickly pulled the US out of the TPP. ${ }^{97}$ Borrowing a page from the Obama Administration, President Trump demanded that South Korea bow to yet another renegotiation of the

\footnotetext{
${ }^{92}$ Jessica Dye, Trump Calls WTO 'Unfair' to US in Latest Trade Barb, Fin. Times, Apr. 6, 2018, https://www.ft.com/content/afce06d0-39aa-11e8-8eee-e06bde01c544.

93 Statement by President Trump on the Paris Climate Accord, THE WhITE House (June 1, 2017), https://www.whitehouse.gov/briefings-statements/statement-president-trump-paris-

climate-accord/.

94 See DSU Art. 3.2.

${ }^{95}$ Naoyuki Toyama \& Rintaro Hosokawa, India, US Combine to Stymie WTO Ministerial Meeting, NIKKEI ASIAN REV. (Dec. 14, 2017), https://asia.nikkei.com/Economy/India-UScombine-to-stymie-WTO-ministerial-meeting; Pradeep S. Mehta \& Bipul Chatterjee, Failure of Latest WTO Summit Reveals an Alarming Global Indifference to Multilateralism, THE WIRE, Dec. 25, 2017, https://thewire.in/208000/wto-summit-failuremultilateralism/?utm_source $=$ alsoread.

${ }^{96}$ Cristiano Lima, Trump Calls Trade Deal 'a Rape of Our Country', POLITICO, June 6, 2018, https://www.politico.com/story/2016/06/donald-trump-trans-pacific-partnership224916.

97 Trump Executive Order Pulls Out of TPP Trade Deal, BBC News (Jan. 24, 2017), https://www.bbc.com/news/world-us-canada-38721056. Trump occasionally expresses non-buyer's remorse about his decision to leave the TPP in the form of saying that the United States may rejoin if it can get a better deal.
} 
KORUS. ${ }^{98}$ KORUS 3.0 further dilutes its free trade content. ${ }^{99}$ For example, the current high US tariff on light trucks is allowed to stay in place for twenty years and the full phase-out of US tariffs to free trade is delayed by twenty-three more years.

The trade agreement that Trump has spent the most time on is the NAFTA. Trump called the NAFTA "the worst trade deal ever made," 100 but unlike his other trade targets, Trump approached the NAFTA more constructively and successfully sought to renegotiate it. The newly redrafted Canada-US-Mexico Agreement (CUSMA/USMCA) ${ }^{101}$ strengthens the NAFTA in many ways while diluting it in several important ways. ${ }^{102}$ Achieving the difficult renegotiation was a diplomatic achievement, and now having gotten it, President Trump seems committed to gaining legislative approval of the new agreement. Trump's new threat to withdraw the US from the NAFTA is being used as a lever to raise his chances of securing Congressional ratification of the new deal. ${ }^{103}$

Borrowing from the TPP language, the CUSMA features new chapters on digital trade, labour, environment, competitiveness, anticorruption, and good regulatory practices. According to Trump, the purpose of the labour and environmental chapters is to "help level the playing field for American workers and businesses and raise standards in these areas." 104 The labour chapter and the other labour provisions are the most far-reaching of any regional trade agreement. For example, Mexico

${ }^{98}$ Daniel Griswold, "Revised" US-Korea Trade Agreement a Small Step Backwards, but Better Than
$\begin{array}{llll}\text { No Agreement, } & \text { THE } & \text { BRIDGE, } & \text { Oct. }\end{array}$ https://www.mercatus.org/bridge/commentary/revised-us-korea-trade-agreement-smallstep-backwards-better-no-agreement.

${ }_{99}$ United States Trade Representative, Fact-Sheet on U.S.-Korea Free Trade Agreement Outcomes (Sept. 2018), https://ustr.gov/about-us/policy-offices/press-office/factsheets/2018/september/fact-sheet-us-korea-free-trade (last visited Feb. 26, 2019).

${ }^{100}$ Nathaniel Parish Flannery, Is Donald Trump Right About NAFTA?, FORBES (Aug. 28, 2017), https://www.forbes.com/sites/nathanielparishflannery/2017/08/28/is-donald-trumpright-about-nafta/\#7072280642e7.

101 The new agreement abandons the "North American" identity of the NAFTA and its environmental side agreement.

102 Daniel J. Ikenson, NAFTA 2.0: The Best Trade Agreement Ever Negotiated (Except for All of the Others), CATO AT LIBERTY (Oct. 8, 2018), https://www.cato.org/blog/nafta-20-besttrade-agreement-ever-negotiated-except-all-others.

${ }^{103}$ David Boddiger, Trump Threatens NAFTA Withdrawal to Pressure Congress on New Trade Deal, SPLINTER (Dec. 2, 2018), https://splinternews.com/trump-threatens-nafta-withdrawalto-pressure-congress-O-1830806422.

104 United States Trade Representative, 2018 Trade Policy Agenda and 2017

Annual Report, The President's Trade Policy Agenda, at 9, https://ustr.gov/sites/default/files/files/Press/Reports/2018/AR/2018\%20Annual\%20R eport\%20I.pdf (last visited Feb. 26, 2019). 
agreed to a specific undertaking to adopt new legislation regarding labour unions and collective bargaining. These concessions are not required of the US and, in some instances, go beyond the labour rights protected by US law. In addition to this, the CUSMA establishes a new labour value content requirement for regional automobile trade linked to a US\$16 an hour minimum wage. ${ }^{105}$ For the CUSMA, the Trump Administration insisted on a 16-year sunset clause that will hinder corporate trade and investment plans. The CUSMA also cuts back on investor protection in Mexico, presumably to discourage private sector investment there.

Trump has backed up his protectionist and pro-tariff rhetoric by actually imposing significant tariffs through Sections 201, 232, and Section 301. The Section 232 tariffs are ostensibly to promote US national security but given the purpose of this law to provide for more industrial self-reliance, the Trump tariffs are effectively a safeguard analogous to the new US tariffs on solar panels. The Section 301 tariffs on China are imposed for the purpose of inducing China to negotiate, but the short-term effects are to grant protection (what Adam Smith referred to above as "transitory inconvenience"). Besides blocking imports with tariffs, Trump has actively sought to block outsourcing of US production to other countries. He has done this by jawboning executives and by threatening tariffs on outsourced production.

The new US policies of import substitution and WTO-bashing are bad for the US, but they are also bad for other countries that may inculcate Trump's anti-trade rhetoric. The world trading system took many decades to design, and Trump's foolish attacks on it may succeed in tearing it down. If so, it will be a demonstration of one of US House of Representatives Speaker Sam Rayburn's many epigrams, viz., that, "Any jackass can kick down a barn, but it takes a good carpenter to build one." 106 The World Bank and the development community have spent many decades seeking to persuade developing countries to adopt constructive trade and development policies and to swear off import substitution. But if the US, the strongest economy in the world, does not believe that it can compete in the world economy without imposing new tariffs, that makes it harder for politicians in every

105 Summary Backgrounder: Canada-United States-Mexico Agreement, GOVT. OF CANADA, https://www.international.gc.ca/trade-commerce/trade-agreements-accordscommerciaux/agr-acc/cusma-aceum/summary-sommaire.aspx?lang=eng (last visited Feb. 6, 2019).

106 More Quotes by Sam Rayburn, FORBESQUOTES, https://www.forbes.com/quotes/author/sam-rayburn/ (last visited Feb. 24, 2019). 
country to stand up to populist pressures to displace imports with domestic production. ${ }^{107}$

Earlier, this article noted that Trump's destructive protectionist rhetoric had a few notable exceptions. The exceptions are that the Trump Administration occasionally seems to support free trade. ${ }^{108}$ In June 2018, US Secretary of State, Mike Pompeo, pointed out that "at the G7, President Trump made very clear we are happy to have 0 percent tariffs on every product. We are happy to eliminate all subsidies. We'd be thrilled to see non-tariff barriers eliminated in their entirety. If every country does that, we will too, and I am confident that will grow America." 109

In July 2018, Trump and European Commission President, Jean-Claude Juncker, agreed to work together toward "zero tariffs, zero non-tariff barriers and zero subsidies on non-auto industrial goods" traded between the US and Europe. ${ }^{110}$ In October 2018, the USTR notified the Congress that it is intending to negotiate trade agreements with Japan, the European Union, and the United Kingdom. ${ }^{111}$ In addition, starting at the WTO 2017 Ministerial Conference, the Trump Administration began working with Japan and the EU to cooperate in seeking multilateral trade reforms outside of the WTO on issues like state-owned enterprises, transparency, and graduation of developing countries. This effort was followed up by a trilateral ministerial meeting in May 2018. Several other plurilateral initiatives exist alongside the WTO such as one being led by Mexico to addresses the regulation of fishery subsidies. Many close observers optimistically view these efforts as having

\footnotetext{
107 See, e.g., Swaminathan S. Anklesaria Aiyar, India's New Protectionism Threatens Gains from Economic Reform, Cato INST. (Oct. 18, 2018), https://www.cato.org/publications/policyanalysis/indias-new-protectionism-threatens-gains-economic-reform.

108 Steve Chapman, The Sudden Emergence of Donald Trump, Free Trader, CHICAGo TribunE, Aug. 3, 2018, https://www.chicagotribune.com/news/opinion/chapman/ct-perspecchapman-trump-free-trade-eu-kudlow-20180803-story.html; Corey Lewandowski, President Trump Continues to Advance Free Trade, THE HILl (Oct. 5, 2018), https://thehill.com/opinion/white-house/409991-president-trump-continues-to-advancefree-trade.

109 U.S. Dep't of State, Remarks on America's Economic Revival, (June 18, 2018), https://www.state.gov/secretary/remarks/2018/06/283305.htm.

110 Remarks by President Trump and President Juncker of the European Commission in Joint Press Statements, THE WHITE HOUSE (July 25, 2018), https://www.whitehouse.gov/briefingsstatements/remarks-president-trump-president-juncker-european-commission-joint-pressstatements. Neither leader explained why automobiles were excluded from the formula. ${ }^{111}$ United States Trade Representative, Trump Administration Announces Intent to Negotiate Trade Agreements with Japan, the European Union and the United Kingdom (Oct. 16, 2018), https://ustr.gov/about-us/policy-offices/press-office/pressreleases/2018/october/trump-administration-announces.
} 
the best potential to overcome the dysfunctions in the W'TO that are preventing progress on new initiatives to open markets and establish better rules. ${ }^{112}$

In summary, between 1934 and 2017, US trade policy has advanced generally in the direction of freer trade, but under the Trump Administration, US policy has retreated away from more open markets and back toward more closed markets. Yet despite the widely shared US income generated by the open trade, the ideological pathology of protectionism has been notoriously difficult to eradicate. Although the Trump Administration is using Section 301 threats, in part, to pry open China's markets (for example, with guaranteed quantities of US imports), the US by its protectionist actions shows the world its belief that closed markets are a smarter policy choice. Leaving open the question of whether infant industry protection is ever appropriate for a developing country, the Trump Administration's tariffs hardly qualify as infant industry protection. Instead, the industries getting the most protection under Trump are the geezer industries (like steel) that have over many decades honed their rent seeking skills.

\section{RETREAT FROM ECONOMIC PEACE}

Trump is the first American President in well over a century to place conflict with other countries at the centre of his foreign policy. A self-proclaimed lover of war, ${ }^{113}$ Trump, as President, has made minatory statements against Canada, the EU, Mexico, South Korea, and Turkey. ${ }^{114}$ And these are America's friends. Trump has made even

\footnotetext{
${ }^{112}$ James Bacchus, Was Buenos Aires the Beginning of the End or the End of the Beginning? The Future of the World Trade Organization, CATO INST. (May 8, 2018), https://www.cato.org/publications/policy-analysis/was-buenos-aires-beginning-end-orend-beginning-future-world-trade/.

113 Brian Chasnoff, Trump: 'T Love War', SAN ANTONIO EXPRESS NeWs, Nov. 13., 2015, https://www.expressnews.com/news/news_columnists/brian_chasnoff/article/Trump-Ilove-war-6630963.php; Nick Gass, Trump Camp Tries To Clarify His 'T Love War' Comment, POLITICO, Sept. 7, 2016, https://www.politico.com/story/2016/09/trump-i-love-warcomment-227818.

${ }^{114}$ Josh Wingrove \& Justin Sink, Trump Threatens Canada 'Ruination' on Autos Amid NAFTA Talks, BloOmBerG, Sept. 8, 2018, https://www.bloomberg.com/news/articles/2018-0907/trump-threatens-canada-s-ruination-on-autos-amid-nafta-talks; Elisabeth Malkin \& Paulina Villegas, After Taunting Mexico, Trump Takes Action With Tariffs. But Do Mexicans Still Care?, N.Y. Times, June 1, 2018, https://www.nytimes.com/2018/06/01/world/americas/mexico-us-tariffs-steeltrump.html; Megan Cassella, Trump Threatens to 'Hold Up' Trade Deal with S. Korea as Leverage in N. Korea Talks, POLITICO (Mar. 29, 2018), https://www.politico.com/story/2018/03/29/trump-south-korea-trade-deal-north-talks450573; Quint Forgey, Trump Threatens Mexico With Economic Devastation, POLITICO JAN. 13,
} 
stronger threats against China, Iran, and North Korea. Trump's embrace of perpetual economic war, somewhat akin to Oceania's wars against Eurasia and Eastasia in Orwell's dystopian novel, 1984, is to confront one country, reach a public entente with it, and then to confront another. Trump's hostility towards Europe ${ }^{115}$ was smoothed over with a deal of sorts, ${ }^{116}$ but EU leaders know that Trump's ire could reignite at any time. In a recent interview, Trump declared that "nobody treats us much worse than the European Union. The European Union was formed in order to take advantage of us on trade, and that's what they've done."117

In Trump's view, trade jihad against other countries is a smart strategy for the US. "Trade wars are good, and easy to win," he boasted in early 2018. ${ }^{118}$ Trump's main weapon is the tariff and he has enthused that "[t]ariffs are the greatest!" 119 Happily for Trump, US law affords him a huge degree of discretion to alter and impose tariffs on foreign countries. But Trump also has other economic weapons at his disposal, and in 2018, the Congress beefed up two of them-the Committee on Foreign Investment in the United States (CFIUS) and export controls. ${ }^{120}$ Both of these programs are targetable against a particular country.

The CFIUS is a Committee of federal cabinet officials (including the USTR) that has authority to regulate active investments by foreign persons in the US. The CFIUS has no public interest members and its proceedings are conducted with little transparency or due process. If the CFIUS finds that a covered transaction presents national security risks, it may seek to impose conditions on foreign investors to mitigate such risks. The CFIUS may also refer the dispute to the President for a final

2019), https://www.politico.com/story/2019/01/13/trump-turkey-isis-syria-withdrawal1098798.

115 Cat Contiguglia, Trump: EU is One of United States' Biggest Foes, Politico (July 15, 2018), https://www.politico.eu/article/donald-trump-putin-russia-europe-one-of-united-statesbiggest-foes/.

116 Damian Paletta \& Jeanne Whalen, Trump, EU Announce Deal to Avert Escalation of Trade Tensions, WASH. POST, July 25, 2018, https://www.washingtonpost.com.

117 Trump Interview with Lesley Stahl, Correspondent, 60 Minutes (Oct. 15, 2018), https://www.cbsnews.com/news/donald-trump-full-interview-60-minutes-transcriptlesley-stahl-2018-10-14/.

118 Thomas Franck, Trump Doubles Down: 'Trade Wars are Good and Easy to Win', CNBC, Mar. 2, 2018, https://www.cnbc.com/2018/03/02/trump-trade-wars-are-good-and-easy-towin.html.

${ }^{119}$ Emily Stewart, Trump Makes His Trade Pmakes his trade itch: Tariffs are the Greatest!, July 24, 2018, https://www.vox.com/2018/7/24/17607182/trump-tariffs-trade-war-taxchina.

120 See Pub. L. 115-232, the Foreign Investment Risk Review Modernization Act (FIRRMA) of 2018 and the Export Controls Act of 2018. 
decision on whether to allow the investment. ${ }^{121}$ Through the CFIUS, the Trump Administration has blocked at least two transactions, the most publicised of which was the proposed acquisition of Qualcomm by the Singapore-based Broadcom. The 2018 statutory revisions expand CFIUS' jurisdiction beyond controlling-interest investments, lengthen the review process, and impose a government fee based on the value of the transaction. ${ }^{122}$

The newly revised export control program grants broader authority to the President to prevent the exports of products and technology whose export could prove detrimental to the national security of the US. But the new law gives 'national security' an open-ended meaning: "The national security of the United States requires that the United States maintain its leadership in the science, technology, engineering, and manufacturing sectors, including foundational technology that is essential to innovation. Such leadership requires that United States persons are competitive in global markets. The impact of the implementation of this part on such leadership and competitiveness must be evaluated on an ongoing basis and applied in imposing controls . . . to avoid negatively affecting such leadership." 123 The law also permits the President to restrict exports to further any US foreign policy.

Together, the expansive new definition of national security combined with the new policy of rendering export controls a discretionary foreign policy tool has potentially changed the legal character of US export controls. Export controls are already a violation of GATT Article XI, but on the assumption that they were closely tethered to national security, there was an assumption in trade law that export controls could be justified by GATT Article XXI. The new US law, by allowing export controls to be used as an instrument of domestic industrial policy, could be found to lack an Article XXI defence.

War is not an end in itself but rather is a strategy to achieve geopolitical aims. The weapons being used by the Trump Administration-export controls, inward investment controls, and tariffs — are at best two-edged swords that hurt domestic

121 The Committee on Foreign Investment in the United States, U.S. DEP'T OF THE TREASURY, https://www.treasury.gov/resource-center/international/foreign-investment/Pages/cfiusoverview.aspx (last visited Feb. 26, 2019).

122 CFIUS ReFORM: THE ForeIgn INVESTMENT Risk REVIEW MODERNIZATION ACT OF 2018, SulLivan \& CROMWELL LLP, https://www.sullcrom.com/files/upload/SCPublication-CFIUS-Reform-The-Foreign-Investment-Risk-Review-Modernization-Act-of20181.pdf (last visited Feb. 26, 2019). The maximum fee is a $\$ 300,000$ subject to inflation adjustments.

${ }^{123}$ Pub. L. 115-232, \$1752(3). 
interests at least as much as they hurt foreign interests. ${ }^{124}$ Export controls and investment restrictions can be a suitable instrument to safeguard national economic security in particular circumstances, but years of usage show that they are prone to being deployed ineffectively and inefficiently. By contrast, tariffs will almost always be an unsuitable instrument to promote national security because a foreign government's retaliation can offset any putative security gains from the tariff. Two other problems with unilateral tariffs are that they are illegal under WTO rules and that they have an import substitutive effect that will signal to tariff targets an ulterior motive of protectionism.

By far, the most significant economic war being waged by the Trump Administration is the cold war against China. ${ }^{125}$ Complaints against China have been accreting for years, but Trump has acted more forcefully against China than Obama or Bush ever did. While the $\$ 344$ billion US trade deficit with China ${ }^{126}$ is the ostensible US complaint, and in 2018, Trump told the UN that the US "trade balance [with China] is just not acceptable," 127 one senses that the Trump Administration's true underlying concern with China is China's challenge to US economic hegemony.

In a recent speech, Vice President Mike Pence laid out a litany of charges against China's policies: "Beijing is employing a whole-of-government approach, using political, economic, and military tools, as well as propaganda, to advance its influence and benefit its interests in the United States ... And the Chinese Communist Party has also used an arsenal of policies inconsistent with free and fair trade, including tariffs, quotas, currency manipulation, forced technology transfer, intellectual property theft, and industrial subsidies that are handed out like candy to foreign

${ }^{124}$ On the pain to the US economy, see Frances Copplla, President Trump's Tariffs Will Hurt Americans More Than China, FORBES, Sept. 18, 2018, https://www.forbes.com/sites/francescoppola/2018/09/18/president-trumps-tariffs-willhurt-america-more-than-china/\#1cc1cce56276; Jeff Stein, Bailout Checks Begin Arriving for Farmers, as Trump's Trade War Escalates, WASH. POST, Sept. 21, 2018, https://www.washingtonpost.com/business/2018/09/21/bailout-checks-begin-arrivingfarmers-trumps-trade-war-escalates/?utm_term=.f4927ec6a3cd.

${ }^{125}$ Michael Bender et al., U.S. Edges Toward New Cold-War Era With China, WaLl ST. J., Oct. 12, 2018, https://www.wsj.com/articles/u-s-edges-toward-new-cold-war-era-with-china1539355839 .

${ }^{126}$ Exbibit 4. Exports, Imports, and Trade Balance of Goods by Country and Area, Not Seasonally Adjusted: 2018, https://www.census.gov/foreign-trade/PressRelease/current_press_release/exh4s.pdf (last visited Feb. 26, 2019).

127 Remarks by President Trump to the $73^{\text {rd }}$ Session of the United Nations General Assembly, THE White House (Sept. 25, 2018), https://www.whitehouse.gov/briefingsstatements/remarks-president-trump-73rd-session-united-nations-general-assembly-newyork-ny/. 
investment ... Now, through the "Made in China 2015" plan, the Communist Party has set its sights on controlling $90 \%$ of the world's most advanced industries including robotics, biotechnology and artificial intelligence ... Worst of all, Chinese security agencies have masterminded the wholesale theft of American technologyincluding cutting-edge military blueprints." 128

Assuming these and similar charges are true, what should the optimal US remedial response be? Answering this question requires distinguishing the contested arenas. They are: (1) China's actions in the US, (2) China's actions in China, and (3) China's actions in the rest of the world.

China's actions in the US are subject to US prescriptive legal jurisdiction. If China is stealing US technology or military blueprints, or interfering with US elections, then the Trump Administration can take direct action to enforce US laws against such guilty actors ${ }^{129}$ and can establish better standards to prevent hacking, cyber theft, and cyberterrorism. Counterintelligence and other defensive measures can also be employed. If China is using propaganda to advance its influence in the US, then little or no governmental response is needed so long as the US marketplace of ideas remains robust and unregulated.

China's actions in China are generally not subject to US prescriptive jurisdiction. So, if China is carrying out unfair acts like forced technology transfer or subsidies to state-owned enterprises, then the US should lodge cases at the WTO if WTO rules are being violated. If China is engaging in unfair actions that are not prohibited by W'TO rules, then the US should work with other WTO members to improve the rules of international trade. US economic nationalism is unlikely to be effective as a way to improve the situation because nationalism per se does not provide model norms for China to adhere to. US sanctions might induce ad hoc concessions by China, such as buying more US soybeans, but while that may gratify US special interests, it will not lead to any long-lasting changes in China's laws or industrial structure. Furthermore, US economic nationalism sends a confused and unappealing message to China that because less open markets can strengthen an economy, the US needs to reduce openness in its markets to gain strength and China needs to expand openness in its markets to reduce strength. In reality, of course, China would get the better of this deal because if China takes Trump's advice to open its markets

128 Remarks by Vice President Pence on the Administration's Policy Towards China, HudsON INST. (Oct. 4, 2018), https://www.hudson.org/events/1610-vice-president-mike-pence-sremarks-on-the-administration-s-policy-towards-china102018.

${ }^{129}$ In late 2018, the Trump Administration stepped up such enforcement. Shannon Vavra, DOJ Launches Initiative to Counter Chinese Economic Theft, AXIOS, Nov. 1, 2018, https://www.axios.com/justice-department-launches-initiative-to-counter-chineseeconomic-theft-jeff-sessions-d83d31ea-0a46-459e-8d48-c505f0ddc933.html. 
then China will get stronger, and if the United States takes Trump's advice to close its markets, then the United States will get weaker.

China's activities in the rest of the world are subject to prescriptive jurisdiction by the rest of the world, but smaller countries may not have strong enough legal systems to take on China. For the rest of the world, even the feckless economic sanctions now being used by the Trump Administration are not an option. If China's actions, such as the Belt and Road Initiative, ${ }^{130}$ are harming other countries, then those countries need multilateral institutions that can enforce international rules against China and prescribe new rules if existing rules are not adequate. For most of the declared US concerns about China, existing rules are not adequate to referee competition between countries with different economic systems. Writing new rules is not an easy process, but deploying US economic nationalism as a substitute, even if it works for the US, will not work for the rest of the world to proselytize China to improve its behaviour.

For all three of the arenas, the common denominator is the need to use international law to influence China. Unfortunately, the Trump Administration has largely dismissed international law in favour of deploying US economic power. Trump sees his trade war against China as an easy win because, as he explains it, the Chinese "don't have enough ammunition to retaliate". ${ }^{131}$ Trump is wrong, however, because China has abundant capacity to inflict harm on the US economy.

Rather than using US economic nationalism, Trump should be utilising WTO influences and processes to raise standards in China. But instead of doing so, the Trump Administration is perversely seeking to diminish WTO influence. The WTO has already proven that it can enforce its law against China. But a W'TO legal system persuasive enough to induce China to comply would also need to be persuasive enough to induce the United States to comply. So, an effective WTO may be a deal breaker for Trump because having an effective international check on US misbehaviour is the last thing he wants. Sadly, the unwillingness of the Trump Administration to strengthen WTO dispute settlement removes first-best rule of law strategies against China and leaves only inferior power-based instruments. It will be hard for the US to persuade China to move toward more market and less government when the US itself is moving toward more government and less market.

130 For a good discussion of the Belt and Road Initiative, see Julien Chaisse \& Mitsuo Matsushita, China's 'Belt and Road' Initiative: Mapping the World Trade Normative and Strategic Implications, 52(1) J. WORLD TRADE 163 (2018).

131 Trump Interview with Lesley Stahl, Correspondent, 60 Minutes (Oct. 15, 2018), https://www.cbsnews.com/news/donald-trump-full-interview-60-minutes-transcriptlesley-stahl-2018-10-14/. 
Trump also pulled the US out of the TPP which the Obama Administration thought could be used normatively to confront greater Chinese influence in the region. ${ }^{132}$ The author's view in 2015 was that the best way for the TPP countries to influence China was to press China to join the TPP negotiations. The TPP is now in force without China or the US, but with North American trade partners Canada and Mexico as parties.

The smartest thing for the Trump Administration to do regarding China would be to gather the EU, Japan, Canada, and a few other countries together to start a highlevel dialogue with China on new rules for China, that would apply equally to all countries. But the Trump-Xi plan seems to provide for only two-party talks which have the obvious danger of leading to ad hoc managed trade solutions that will externalise costs on third countries. The author is not aware of any analytical work to draft a new code to distinguish what China is doing wrong in its industrial policy from what China is doing right.

Honest observers cannot fail to be impressed by China's ambitions in its 2025 plan to expand its manufacturing and innovative capacity in the world's most advanced industries. Indeed, the author would hypothesise that if offered a veiled choice between the China model of an industrial policy that supports the industries of the future (like robotics, biotechnology, and artificial intelligence) and the US model of an industrial policy that supports the industries of the past (like steel, aluminium, and washing machines), most consumers and producers around the world (and indeed within the US) would choose the China model.

The same is true for the Belt and Road Initiative where China is seeking to establish a large economic area in which participants will cooperate for co-prosperity. ${ }^{133}$ As described by Matsushita and Chaisse, China's initiative entails gargantuan publicprivate investments in regional infrastructure linked together with expanded production, jobs, trade, and investment. The regional infrastructure includes railways, highways, pipelines, electrical transmission networks, and airports, to name a few. The Initiative gives China a way to expand its development model which if successful and environmentally sound will enhance Chinese and regional prosperity.

\footnotetext{
132 See Barack Obama, President Obama: The TPP Would Let America, Not China, Lead the Way on Global Trade, WASH. POST, May 2, 2016, https://www.washingtonpost.com/opinions/president-obama-the-tpp-would-let-americanot-china-lead-the-way-on-global-trade/2016/05/02/680540e4-0fd0-11e6-93ae50921721165d_story.html?utm_term=.e71528e9f22e.

${ }^{133}$ Chaisse \& Matsushita, supra note 130, at 185.
} 
As China proceeds in this direction, the United States under Trump seems to be going in the opposite direction with inward directed policies rather than outwardly directed ones. Trump's feckless economic policy is unexportable to other countries and so, unlike China, US influence in other countries is contracting not expanding. In its first two years, the Trump Administration failed to achieve any significant expansion of infrastructure and the defining infrastructure project for Trump has been to build a wall on the US side of the Mexican border. And even if the wall gets built, which in January 2019 seems doubtful, the wall is designed to prevent the movement of people rather than to generate new economic activity.

Although the Trump Administration's war against China is in part an effort to bring China to the negotiating table to address the US-China bilateral deficit, the Administration also seems to have a long game in mind of making China a less attractive place to invest and relocating production from China to the US. ${ }^{134}$ In the new CUSMA, the Trump Administration inserted an unprecedented FTA provision to discourage the TPP from adding China and to discourage Canada or Mexico from negotiating with China. ${ }^{135}$ Such actions can backfire if they lead China away from internationalism. The dangers to US national security from Chinese steel exports to the US will pale next to the dangers if China starts to act aggressively against US interests - for example, regarding North Korea, the South China Sea, the UN Security Council, and the climate regime.

In summary, Trump's trade wars are intended to strengthen the United States at the expense of trading partners. Because Trump's policies have been so ill-considered and carelessly implemented, the net impact will probably be to strengthen other countries, particularly China, while weakening the United States. With its smart, strategic leadership and its ability to launch and carry out multi-year economic policies, the Chinese economy seems more likely to emerge from the trade wars with less damage than will be imposed on the US economy from Trump's trade wars.

\section{RETREAT FROM THE GLOBAL ORDER}

\footnotetext{
${ }^{134}$ Bob Davis, U.S. Tariffs on China Aren't a Short-Term Strategy, WALL ST. J., Oct. 8, 2018, at A2, https://www.wsj.com/articles/u-s-tariffs-on-china-arent-a-short-term-strategy1538841600 .

135 Mike Blanchfield, Beijing Attacks USMCA Clause Seen as Blocking Efforts to Expand Trade With Canada, Mexico, CBC (Oct. 6, 2018), https://www.cbc.ca/news/politics/usmca-naftachina-trade-1.4852269. The provision would call into question the continuation of the Agreement if one of the three parties negotiated a free trade agreement with a non-market economy. See Article 32.10 of the USMCA/CUSMA.
} 
In his 2018 address to the UN, President Trump asserted that his Administration's foreign policy is "principled realism". ${ }^{136}$ At least for trade, his assertion is untrue because his trade policies are neither principled nor attuned to realism. Trump's trade policies are not principled because they violate positive international law and because they fail Kant's categorical imperative to act only in a way that you would want other countries to act toward you. ${ }^{137}$ Trump's policies are not oriented towards realism because they fail to take into account that his methods will not achieve the goals of making America great again or influencing other countries to be more cooperative with the US. Indeed, Trump's policies are more likely to undermine those goals.

President Trump's Administration has repeatedly invoked the mantra of 'sovereignty' by which he apparently means to keep US policymaking untethered from the global order. In the same address, Trump warned that "America will always choose independence and cooperation over global governance, control, and domination ... We reject the ideology of globalism, and we embrace the doctrine of patriotism. Around the world, responsible nations must defend against threat to sovereignty not just from global governance, but also from other, new forms of coercion and domination . . . [W] e must protect our sovereignty and our cherished independence above all."'138

In his 2017 address to the UN, Trump had declared: "As President of the United States, I will always put America first, just like you, as the leaders of your countries will always, and should always, put your countries first. All responsible leaders have an obligation to serve their own citizens and the nation-state remains the best vehicle for elevating the human condition."139

136 Full Text: Trump's 2018 UN Speech Transcript, POLITICO (Sept. 25, 2018), https://www.politico.com/story/2018/09/25/trump-un-speech-2018-full-text-transcript840043.

137 Robert Johnson \& Adam Cureton, Kant's Moral Philosophy, Stanford Encyclopedia of Philosophy (Feb. 23, 2004), https://plato.stanford.edu/entries/kant-moral/. Trump's policy fails the test of the categorical imperative because his Administration would not want every country to write its own biased version of Section 301 and impose locally convenient tariffs against the United States.

138 Remarks by President Trump to the $73^{\text {rd }}$ Session of the United Nations General Assembly, THE White House (Sept. 25, 2018), https://www.whitehouse.gov/briefingsstatements/remarks-president-trump-73rd-session-united-nations-general-assembly-newyork-ny/.

139 Remarks by President Trump to the $72^{\text {nd }}$ Session of the United Nations General Assembly, THE White House (Sept. 19, 2017), https://www.whitehouse.gov/briefingsstatements/remarks-president-trump-72nd-session-united-nations-general-assembly/. 
Trump is not incorrect to praise the nation state, but his policies elide the two most serious pathologies of the nation state: (1) its treatment of other nation states and (2) its treatment of its own citizens. Although there is nothing morally wrong with each country putting itself first, it is wrong for a country to use means that injure other countries. For hundreds of years, civilised countries have developed international legal norms to provide rules for how countries should treat each other. Such international law is particularly well developed regarding the use of military force and the use of trade policy. As explained earlier in this article, Trump's economic nationalism violates the international trade law written to cabin economic nationalism.

The reverse of imposing economic policies that externalise costs on other countries is the crafting of economic policies that externalise mutual benefits among countries. Some parts of Trump's first trade agreement, the CUSMA, do just that, but for the most part, Trump's trade policies have missed out on many opportunities to enhance mutual gains through trade cooperation. Trump's trade myopia stems from his flawed understanding of international trade as a zero-sum game where one country wins and another loses.

The second pathology of the nation state is the mistreatment of its domestic citizens and residents. Efforts to address this problem go back to antiquity, but the most important early landmark in granting individuals rights against the nation state was the Magna Carta in 1215. Over the past century, international law has fructified to delineate and enforce labour rights, human rights, and more recently, environmental rights. These developments reflected an understanding of the transnational essence of individual rights as being rights of humanity rather than rights granted by each particular nation state. The global order began to blossom centuries ago to promote social goals that could not be compartmentalised within one nation. Intellectual property, communications and transportation infrastructure, and the environment are examples of the many fields where international cooperation can be essential.

During the 20th century, there was a growing recognition of some public goods as being planetary in nature, such as concerns about climate change. ${ }^{140}$ The Trump Administration's criticism of global governance and embrace of global disorder is an especially dangerous conceit on a planet where climate change has become not only a premier global environmental issue but also a premier economic issue. ${ }^{141}$ When

140 Ernst-Ulrich Petersmann, Multilevel Constitutionalism for Multilevel GovernanCE OF Public GoOds (2017).

${ }^{141}$ Coral Davenport, Major Climate Report Describes a Strong Risk of Crisis as Early as 2040, N.Y. TiMES, Oct. 7, 2018, https://www.nytimes.com/2018/10/07/climate/ipcc-climate-report2040.html. 
governments finalised the Paris Agreement on climate in December 2015, their efforts received great acclaim. President Obama called it "the strong agreement the world needed." 142 The venerable newspaper The Guardian (of London) praised it as "the world's greatest diplomatic success". ${ }^{143}$ The sad reality, however, is that the Paris Agreement, from the start, was inadequate to address the problem, and in the three years since its adoption, the gap has widened between what needs to be done to reverse climate change and what the Paris Agreement accomplishes. ${ }^{144}$

The Paris Agreement, which aims to hold the increase in the global average temperature to less than two degrees Celsius above pre-industrial levels, employs the instrument of "nationally determined contributions" (NDCs) reflecting each party's individualised commitment. The Agreement contains transparency requirements regarding the reporting of NDCs and provides for the establishment of an expertbased committee to facilitate implementation and "promote compliance" in a manner that is "non-adversarial and non-punitive". The only legal obligations, however, are procedural; the Agreement does not oblige a country to actually achieve its NDC but only to aim to achieve it. Although the Paris Agreement is sometimes criticised as being 'non-binding' or 'voluntary', such criticisms are off the mark. The Paris Agreement does contain legal obligations for governments in the manner of any treaty. What is missing is a depth of substantive obligation that can reasonably be expected to halt (or even slow down) the global warming crisis.

The Paris Agreement provides a framework for cooperation but lacks any undertaking on specific regulations or taxes (like a carbon tax) to be enacted. The Agreement addresses the problem of free riders with a trigger for going into force, but it does not reflect any prior negotiation as to the total quantity of emission reduction to be achieved by the NDCs or as to the fairness of the NDC commitments offered up by individual countries. Thus, compared to trade negotiations, which typically do not conclude without a tangible agreement based on reciprocity, the Paris negotiations yielded a package of emission commitments without any quantum of achievement being required ex ante and without any balance

142 Statement by the President on the Paris Climate Agreement, THE White House (Dec. 12, 2015), https://obamawhitehouse.archives.gov/the-press-office/2015/12/12/statement-

president-paris-climate-agreement,

${ }^{143}$ Fiona Harvey, Paris Climate Change Agreement: The World's Greatest Diplomatic Success, THE GUARDIAN, Dec. 14, 2015, https://www.theguardian.com/environment/2015/dec/13/paris-climate-deal-copdiplomacy-developing-united-nations.

${ }^{144}$ Coral Davenport \& Kendra Pierre-Louis, U.S. Climate Report Warns of Damaged Environment and Shrinking Economy, N.Y. TIMES, Nov. 23, 2018, https://www.nytimes.com/2018/11/23/climate/us-climate-report.html; Rick Samans, The Paris Accord Won't Stop Global Warming on Its Own, FOREIGN POL'Y (Sept. 26, 2018), https:// foreignpolicy.com/2018/09/26/the-paris-accord-wont-stop-global-warming-onits-own/. 
of national commitments. In addition, the climate regime continues to dodge the difficult question of how to allocate state responsibility for the embedded carbon emissions in internationally-traded goods. At present, the climate regime is seemingly turfing this problem to the trading system, but that is an improper delegation because at best, the W'TO dispute system can only allow unilateral solutions. The WTO lacks the jurisdiction to make a climate based judgment about who should be responsible for curtailing the emissions embedded in the production of imported or exported products.

As noted above, the Obama Administration pursued climate negotiations without doing any legislative heavy lifting but rather relied upon executive authorities to ratify and implement the Agreement. This dubious policy choice made the Paris Agreement vulnerable to a new Administration with different views about climate and the Paris Agreement. Trump campaigned against the Paris Agreement and after his election, he initiated a mechanism to withdraw the US from the Agreement. In announcing the US withdrawal, Trump declared:

"As someone who cares deeply about the environment, which I do, I cannot in good conscience support a deal that punishes the United States - which is what it doesthe world's leader in environmental protection, while imposing no meaningful obligations on the world's leading polluters. For example, under the agreement, China will be able to increase these emissions by a staggering number of years13. They can do whatever they want for 13 years. Not us ... Even if the Paris Agreement were implemented in full, with total compliance from all nations, it is estimated it would only produce a two-tenths of one degree - think of that; this much - Celsius reduction in global temperature by the year 2100 . . I'm willing to immediately work with Democratic leaders to either negotiate our way back into Paris, under the terms that are fair to the United States and its workers, or to negotiate a new deal that protects our country and its taxpayers ...

... Foreign leaders in Europe, Asia and across the world should not have more to say with respect to the US economy than our own citizens and their elected representatives. Thus, our withdrawal from the agreement represents a reassertion of America's sovereignty ...

... As President, I have one obligation, and that obligation is to the American people. The Paris Accord would undermine our economy, hamstring our workers, weaken our sovereignty, impose unacceptable legal risks, and put us at a permanent disadvantage to the other countries of the world. It is time to exit the Paris Accord and time to pursue a new deal that protects the environment, our companies, our citizens and our country." 145

145 Statement by President Trump on the Paris Climate Accord, THE WHITE House (June 1, 2017), https://www.whitehouse.gov/briefings-statements/statement-president-trump-parisclimate-accord/. 
Although Trump's announced Paris withdrawal has been roundly criticised, his complaints about the Paris Agreement are far more justified than his complaints about the WTO or world trade. Trump is correct that the Paris Agreement imposes no meaningful obligations on the world's leading carbon emitters including the US. Trump is correct that the Paris Agreement falls far short of addressing global warming. ${ }^{146}$ But Trump is wrong to suggest that the Paris Agreement infringes on US sovereignty or that pulling out reasserts US sovereignty any more than staying in would. The statist essence of the Paris Agreement means that it cannot threaten sovereignty but it also means that it may not be able to solve the climate crisis.

Climate change may be the quintessential global issue that cannot be solved without cooperation of the largest countries. In that sense, climate change is different from many other putative global issues_-such as human rights, democracy, water pollution, free trade, and peace-where single or smaller groups of countries can achieve these goals without buy-in by all countries. For a true global issue like climate change, the principles of subsidiary would suggest that the nation state is too low a level at which to formulate successful climate policy. Instead, decision-making needs to occur at a global level, but the obvious challenge is that we lack governmental institutions at the global level to champion global interests and the interests of humanity. In addition, while there has long been recognition of an inchoate cosmopolitanism community, our civic and business institutions are also remarkably weak at the global level. If there is any hope for climate efforts to become much more effective, what is needed is major technological breakthroughs on nuclear power or geoengineering or major political breakthroughs on imposing a large carbon tax among a critical mass of countries.

\section{CONCLUSION}

In my 2005 article, "The World Trade Organization in 2020", 147 I offered some predictions of what the WTO might look like in 2020, considering both a pessimistic scenario and an optimistic scenario. In the pessimistic scenario, I posited that the WTO would deteriorate and become ineffective should the Doha Round fail or should a major country, like the US, pull out of the WTO. My article doubted that such a dystopian scenario would materialise.

\footnotetext{
146 Steven Mufson, 'A Kind of Dark Realism': Why the Climate Change is Starting to Look Too Big to Solve, WASH. POST, Dec. 4, 2018, at A1.

${ }^{147}$ Steve Charnovitz, The World Trade Organization in 2020, 1 J. Int'l L. \& Int'l Rel. 167 (2005), reprinted in STEVE CHARNOVITZ, THE PATH OF WORLD TRADE LAW IN THE 21ST CENTURY, 715-40 (2015).
} 
Certainly in 2005, I did not foresee President Trump coming to power on an antitrade, anti-international law platform. President Trump's new tariff policy is uniquely American in ambition, iconoclasm, and foolishness. Only the US could afford to give up so much national income and would have the temerity to violate so many international commitments. Among leading democracies, only the US has given its President so much statutory discretion to wage economic war. ${ }^{148}$

This article examines Trump's evolving international economic policies and reaches the conclusion that the new US policies threaten the rule of law, free markets, world peace, and the global public order. Although many of President Trump's words and actions have been unfortunate, he has voiced a few good ideas that could be packaged into a progressive program on both trade and climate.

On trade, the Administration should seek to reinvigorate the WTO and to start new negotiations with a goal of moving toward "zero tariffs, zero non-tariff barriers and zero subsidies". On climate, the Trump Administration should seek to pursue a new deal with the objective of achieving balanced and substantial national commitments sufficient to meet the goals that climate scientists have set. Although zero tariffs are a worthy goal, Trump's other zero goals run up against valid economic objections. For non-tariff barriers, there is a need to distinguish between barriers that are justified for policy reasons, such as an environmental regulation, and barriers that are merely protectionist. For subsidies, there is a similar challenge, because many subsidies are useful to correct market failure. Linking zero tariffs to a non-trade objective may help politically in achieving trade liberalisation. That was the idea behind the Doha Round's agenda item of lowering tariffs on environmental goods. Based on the same logic, environmental groups tried to add a Doha Round goal of eliminating subsidies on fossil fuels but were unsuccessful in doing so. Even the less controversial agenda item endorsed by the WTO, of eliminating overfishing subsidies, could not be achieved in the Doha Round.

The Doha Round did not enjoy a great deal of public support, but if governments had sought to repackage those negotiations around the objective of sustainable development, that might have been a path toward lifting public support and making the Round more politically capable of being achieved. ${ }^{149}$ Now that Doha appears to be dead, new progress might be achievable along these lines in new plurilateral negotiations.

\footnotetext{
148 US Presidents also have unusually high discretion to wage military wars.

149 For further discussion, see JAMES BACCHUS, THE WiLling World. SHAPING AND Sharing a Sustainable Global Prosperity (2018); Ryerson Neal, Trade and Climate Change: Synergy and Conflicts, CTR. INT’L GOVERNANCE \& INNOVATION (Jul. 30, 2018), https://www.cigionline.org/publications/trade-and-climate-change-synergies-andconflicts.
} 
On climate, the Trump Administration should seek to pursue a new deal with the objective of achieving balanced and substantial national commitments sufficient to meet the goals that climate scientists have set. Several serious flaws in the Paris Agreement need to be addressed. First, the totality of individual governmental 'contributions' falls far short of what is needed to reverse climate change. Second, the individual government-offered contributions are imbalanced and un-reciprocal, and do not take into account transborder flows of goods, services, and investment. The beginning of wisdom is to acknowledge those flaws and begin to redesign the Paris Agreement to render it less hollow. Trump's distance from the Paris Agreement gives him an opportunity to call for global efforts to fix it.

As a first step, the climate regime should strongly recommend that governments adopt a hefty carbon charge consistent with the OECD's polluter pays principle. In so doing, the effective date of the carbon charge should be set based on the attainment of a critical mass of major economies that will also impose the carbon charge. ${ }^{150}$ The recent protests in France over the proposed fuel tax shows the difficulties in asking the public to make unrequited sacrifices. ${ }^{151}$ Equally important to a carbon tax, governments should agree to sharply step up long-term investment in research and technology to improve carbon capture and explore geoengineering. Signing on to these two initiatives by President Trump, or his successor, would help to make the world economy great again and to make the Earth healthy again.

\footnotetext{
150 Such a contingent carbon charge was recommended by Daniel C. Esty and Steve Charnovitz in 2012. See Daniel C. Esty \& Steve Charnovitz, Green Rules to Drive Innovation, HARV. Bus. REV. (Mar. 2012), https://hbr.org/2012/03/green-rules-to-drive-innovation (last visited Feb. 26, 2019). But see Zack Colman \& Eric Wolff, Why Greens are Turning Away From a Carbon Tax, POLITICO (Dec. 8, 2018), https://www.politico.com/story/2018/12/09/carbon-tax-climate-changeenvironmentalists-1052210.

151 The Editorial Board, The Global Carbon Tax Revolt, Wall ST. J., Dec. 3, 2018, https://www.wsj.com/articles/the-global-carbon-tax-revolt-1543880507; The Editorial Board, Macron's Climate Plan B, WALL ST. J., Dec. 4, 2018, https://www.wsj.com/articles/macrons-climate-plan-b-1543965655.
} 